\title{
A MAGYAR BANKSZÖVETSÉG TAGBANKJAI
}

Vass Péter

A Bankszövetség 30 éves fennállása alatt rendkívüli fejlödésen ment át a bankszektor. ${ }^{1}$ Ez időszakban összességében 93 bank működött Magyarországon bejegyzett intézményként (részvénytársasági és fióktelepi formában), egy időpontban a számuk jellemzően 40 és 50 közé esett. Ezt meghaladó számban csak speciális okok miatt voltak jelen, míg 40 alatt a kétszintű bankrendszer kialakítását követő átalakulási, majd a rendszerváltást követő bankalapítási láz idején egészen 1991-ig, illetve - látszólag - meglepetésre, a 2000-es évek eleji bankpiaci boom időszakában voltak.

Az intézményi struktúra kialakulása, illetve folyamatos változása hátterében a hazai fejlődési folyamatok mellett - ideértve a banküzemi, a konjunkturális és a szabályozási fejlődést - a nemzetközi strukturális fejlemények (összeolvadások, stratégiai szövetségek és azok felbomlásának) magyar leánybanki leképeződései és egyedi banki fejlődéstörténetek is állnak. A terjedelmi korlátok nem adnak lehetőséget ezek együttes, mélyreható kifejtésére, azonban hasznos lehet egy közös keretben bemutatni a Bankszövetség tagbankjainak fejlödését a jelenleg is tagjaink sorában lévőkre koncentrálva.

JEL-kódok: G21, N94

Kulcsszavak: bankszektortörténet, banktörténet, bankpiacra belépés, bankpiacról kilépés, banki összeolvadások, verseny

\section{RÖVIDENA BANKSZEKTOR 30 ÉVES FEJLÖDÉSÉRŐL}

A Magyar Bankszövetség fennállásának 30 éve önmagában nem értékelhető anélkül, hogy ne vennénk szemügyre a pénzügyi szektorban az 1980-as években zajló változásokat. Magyarország bekapcsolódása a fejlett nemzetközi pénzügyi vérkeringésbe, illetve a magángazdaság felé nyitás és a pénzügyi szolgáltatásokkal kapcsolatos, ebből fakadó igények a monolitikus pénzügyi szerkezet határait feszegették. Politikai szinten az évtized közepére megszületett a döntés a kétszintü bankrendszer kialakítására és a belföldi vállalati pénzügyi szolgáltatások libera-

1 A jelen anyag értelmezésében a bankszektor körébe tartozónak tekintendők a Hpt. szerinti bankok és szakosított hitelintézetek, ide nem értve a nem bankszerű tevékenységet végző KELER-t. Bár a jelenlegi felügyeleti statisztikák ebbe a körbe tartozónak tekintik 2008-tól a prudenciális szempontból a hitelintézetekkel egy tekintet alá eső pénzügyi vállalkozásokat is (ezek leginkább a garanciaintézmények: GHG, AVHGA, MV), itt azonban nem szerepelnek. 
lizálására ${ }^{2}$, ennek során kialakultak az évtized végének nagybankjai. Azonban azzal, hogy a liberalizáció első jeleire néhány külföldi bank (Citibank, Raiffeisen) vegyesvállalatok alapításával reagált, valamint az évtized elejétől megalakuló, ágazati pénzügyi alapok egyre inkább bankszerű működésével és bővülő jogosítványaival ${ }^{3}$ mikroszintről kiindulva is jelentős mértékben fejlődött a szektor. Ez utóbbi intézmények adták az évtized végére a kis- és középméretü intézmények zömét.

A pénzintézeti struktúra átalakítása és az új társasági jogszabályokat követő, tömeges részvénytársasággá alakulás, valamint a politikai átrendeződéssel együtt járó, további liberalizáció - amely lassan átterjedt a helyhatósági és a lakossági pénzügyekre is - bankalapítási, illetve a meglévő bankok esetében hálózatbővítési hullámot indukált.

Így érünk el a Bankszövetség alapításának időpontjához, amelyet a Fővárosi Bíróság 1989 februárjában jegyzett be. ${ }^{4}$

Ezt az expanziós időszakot a magyar gazdaság (illetve mondhatjuk, hogy a KGST összeomlásával a teljes keleti blokk) transzformációs, illetve a bankszektor ebből és egyéb fejlődési és szabályozási folyamataiból, hibáiból eredő (öröklött adósok minősége ${ }^{5}$, a nagy adós állami vállalatok részvétele a banki tulajdonlásban, alultőkésítettség, bázeli tőkekövetelmény és hitelkockázati szabályozás átmenet nélküli bevezetése, új csődtörvény kötelező öncsőddel ${ }^{6}$ stb.), hitelkockázati és tőkeválsága zárta 1991-92-ben. Ezt előbb a hitel-, majd a bank- és adóskonszolidáció állami programjai követték 1993-94-ben államkötvényhitel-cserével és nagy eszközleírásokkal, valamint 8 bank feltőkésítésével (Agrobank, Dunabank, Iparbankház, Mezőbank, Takarékbank, Budapest Bank, K\&H, MHB).? Az újonnan, zöldmezős beruházással alakult, külföldi tulajdonú leánybankok, illetve vegyesbankok zömét alig érintették a fenti válságjelenségek, így az 1990-es évek első felében folyamatosan eredményesen bővültek jó tőkeellátottságuknak és kedvező versenypiaci pozícióiknak köszönhetően. ${ }^{8}$ Ezen időszak alatt a vegyesbankokban a külföldi szakmai tulajdonrész folyamatosan növekedett, nemegyszer stratégiai befektető váltása mellett.

A jelentős költségvetési forrásokat felemésztő konszolidáció eredményeképpen elindulhatott az állami tulajdon értékesítése, amely ebben az időszakban még mindig a kétharmadát tette ki a szektor teljes jegyzett tőkéjének. ${ }^{9}$ A megelőző,

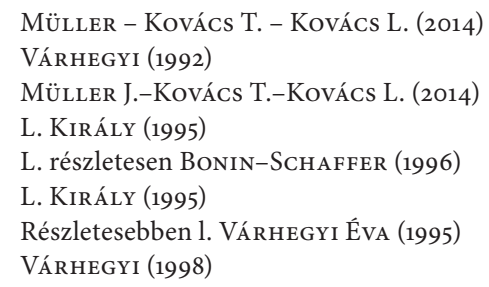


több mint fél évtized tanulságai alapján a tőkeszükségletet biztosító és a banküzem érdemi fejlesztésére képes szakmai befektetők lettek a privatizáció célcsoportja, és ettől számosságában elenyésző esetben, nemzetgazdasági stratégiai szempontok miatt tértek el (például lásd az OTP privatizációját, amely időben a többi nagybankhoz képest némileg korábban indult, lezárása pedig hosszabb időt vett igénybe). A privatizáció érdemi szakasza 1995-97 közé tehető, és az a sajátossága, hogy a részvények névértékét lényegesen meghaladó áron keltek el a nagybankok. ${ }^{10}$ Fontos kiemelni itt az EBRD katalizáló szerepét, amely a szakmai befektetők kockázatai egy részének az átvállalásával ideiglenes tulajdonrészt szerzett több bankban $(\mathrm{BB}, \mathrm{K} \& \mathrm{H}, \mathrm{MKB})$. A privatizáció végére az állam részesedése a szektor intézményeiben 20 százalék környékére csökkent, és a külföldi tulajdon a megelőző 16-ról 60 százalék fölé növekedett. ${ }^{11}$ A tulajdoni struktúra lényegében ezzel közel másfél évtizedre rögzült, illetve hamarosan kialakult a mai napig jelenlévő, legfontosabb stratégiai befektetői kör, amely leginkább az anyabanki akvizíciók és stratégiai együttműködések dinamikájának eredményeként változott.

A privatizációt követően megkezdődött egy tízéves, intenzív építkezési szakasz a bankszektorban, amely a mennyiségi jellemzők mellett a termékválaszték és a banküzemi infrastruktúra jelentős fejlődésében is megmutatkozott. Ennek során a hazai bankszektor a modern európai banki közösség teljes jogú tagjává vált. ${ }^{12} \mathrm{Az}$ időszak szakirodalmának a fókuszában a kifejezetten banküzemi témák mellett ekkor elsősorban a banki közvetítés mélysége és ennek hatása a gazdaság teljesítményére, a bankpiac versenyző vagy oligopolisztikus jellege, valamint a külföldi tulajdonnal kapcsolatos, korábbi várakozások visszamérése állt.

Az expanzió során a jelentősen megerősödött, külföldi tulajdonú nagybankok erős versenyben álltak egymással, és ha az OTP Csoport piacvezető helyét összességében nem is veszélyeztették, de egyes részpiacokon komoly kihívóiként léptek fel. Az árversenyt az időszak második felére fokozatosan kiegészítette egy kiélezett, kockázatalapú verseny ${ }^{13}$, elterjedtek a devizahitelek és lazultak a hitelezési feltételek minden ügyfélkör esetében, az időszak végére lakossági oldalon elterjedt gyakorlattá vált a tisztán fedezetalapú hitelezés és az önerő egészségtelenül alacsony szintje a hosszú távú hitelezésben.

Az időszak egy másik jelentős folyamata, illetve eseménye Magyarország uniós csatlakozása volt. Ennek a szabályozási kérdések mellett két jelentősebb hatása érdemel említést a bankszektorra gyakorolt befolyása miatt. A csatlakozási szerződésben szerepelt az euróövezeti csatlakozásunk kötelezettsége, amelyre több céldátumot is bejelentettek az akkori kormányok. Az adott helyzetben így a ver-

10 Ábel-Szakadát (1997)

11 VÁrhegyi (2001)

12 MÜller J. - KovÁcs T. - KovÁcs L. (2014)

13 Lakossági oldalon részletesen kifejtve: KIRÁLY-NAGY (2008) 
senyképességi mellett kockázati szempontból is racionális lépés volt akkor az euróban történő finanszírozás bevezetése. Másik a letelepedési szabadság miatti félelem attól, hogy a hazai bankok tömegesen fióktelepekké válnak, ami vélhetően az akkori éles versenyhelyzetben csak félelem maradt, és a válság beköszöntével is csak mérsékelten jelentkezett.

A válság 2008-ban rendkívül sérülékeny állapotban érte a gazdaságot. Ennek egyik fontos oka a magángazdaság magas eladósodottsága és devizális szerkezete volt. A pénzügyi piacok szinte azonnal lefagytak, de a jegybank likviditásbővítő intézkedései, valamint a kormány hitelfelvétele az IMF és EU párostól, valamint a betétek garantálásával kapcsolatos kormányzati nyilatkozatok segítettek viszonylagos nyugalmat teremteni. ${ }^{14} \mathrm{~A}$ külföldi stratégiai tulajdonosok biztosították a biztonságos működéshez szükséges tőkét, és ebben a korai szakaszban nem vontak el finanszírozási forrásokat a több esetben saját államuk által biztosított eszközökből.15 A magyar tulajdonú, illetve irányítású bankok részére a magyar állam biztosította a mentőövet az említett nemzetközi hitelböl ${ }^{16}$, amelyből az OTP csak hamar előtörlesztett eurófinanszírozási forrást, az FHB ezen túl tőkejuttatást is igénybe vett. A gazdaság 2009. évi visszaesése és ennek hatása az adósi körre elörevetítette a bankszektor teljesítményének hosszabb távú visszaesését, amit a 2010-es választást követő kormányzati intézkedések banki terhei „hét szűk esztendővé" dagasztottak. Kiemelkednek az intézkedések köréből a szektorspecifikus közterhek, a hitelintézeti különadó (2010), amely indulásakor 120 milliárd/év nagyságrendủ volt ${ }^{17}$, és a mai napra harmadolódott, továbbá a pénzügyi tranzakciós illeték, amely 130 milliárd forint bevételt célzott meg indulásakor ${ }^{18}$, majd ennek csaknem másfélszeresét szedték be 2013-tól kezdődően évről évre. Ugyancsak fontos, de egyszeri terheket jelentettek az adósmentő akciók: a kedvezményes végtörlesztés 2012-ben az akkori saját tőke mintegy 10 százalékát, az elszámolás 2015-ben annak mintegy egynegyedét emésztette fel végül. Ennél némileg kisebb összegü, azonban jelentős operációs terheket jelentő intézkedéseket is bevezettek (árfolyamgát 1-2, Nemzeti Eszközkezelö), mindezekkel a bankok a problémával küzdő ügyfelek mintegy kétharmadát elérték. ${ }^{19}$ Jelentős közvetett hatással bíró folyamat volt a takarékszövetkezeti csődök sora ${ }^{20}$, amelynek részben következménye, részben - a kötelező átvilágításokból eredően - előidézője volt az új, már nem megállapodáson alapuló, hanem törvény által irányított takarékszövetkezeti integráció létrehozása. Az ebből eredő kártalanítások, amelyeket súlyosbított a

\footnotetext{
14 Banai-Király-Nagy (2010)

15 Vienna Initiative 1-2.

16 L. 2008. évi CIV. törvény a pénzügyi közvetítőrendszer stabilitásának erősítéséről

17 Kovács L. (2012)

18 Uo.

19 Kovács L. (2014)

20 Kovács L. (2015)
} 
Buda-Cash- és a Quaestor-ügy, 2015-re a vagyonvesztés mellett jelentős mértékben eladósította az OBA-t és a BEVA ${ }^{21}-t, s$ az adósság jelentős részét, valamint az elöírt vagyonszintet a bankszektornak kellett, illetve kell pótolnia.

2016-ban érkezünk a bankszektor fejlődésének jelenlegi szakaszába, ellenállóbb gazdasággal, jóval összetettebb szabályozási és felügyeleti rendszerekkel, a digitalizáció új kihívásaival és az EU bankszektorait látszólag meghaladó eredményességgel. ${ }^{22}$ A makropénzügyeknek az adott viszonyok közötti kiegyensúlyozását követően, az EBRD-vel kötött megállapodás részeként vállalt kötelezettségek eredményeként normalizálódott a kormányzat és a bankszektor viszonya, és lehetőség nyílt egy prosperáló, versenyző időszak megindulására.

\section{1. ábra}

\section{A bankszektor mérlegföösszegének és a banki penetrációnak az alakulása}

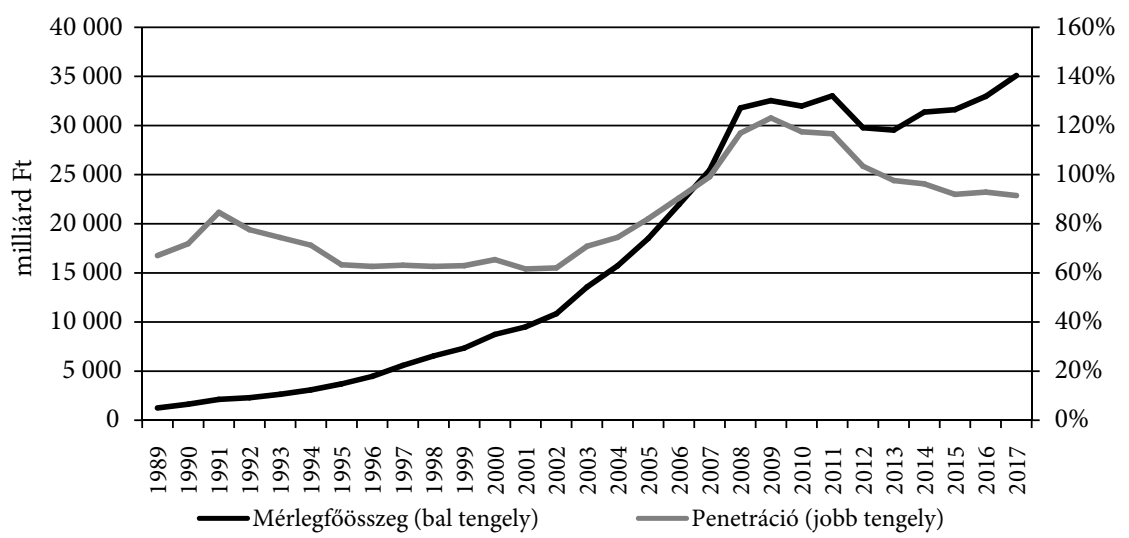

Forrás: Király (1995), Várhegyi (2002), ÁPTF éves jelentések, PSZÁF- és MNB-statisztikák, KSH

\section{A BANKSZÖVETSÉG TAGJAINAK FEJLÖDÉSE 1989-2018 ${ }^{23}$}

A továbbiakban a magyar piacon működő bankok elmúlt harminc évének legfontosabb mozzanatairól és a bankszektorban betöltött szerepükröl, súlyukról lesz szó. Terjedelmi korlátok miatt csak a leglényegesebb fejlemények kerülhettek ide.

21 Ehhez adódott még az is, hogy a Quaestor-ügy hatására az EU-ban is bőkezűnek számító szintre emelték a BEVA-kártalanítási értékhatárt.

22 SzentPéteri-BeCSEI-DÁNYi-Bógyi (2017)

23 A további részek elkészítésében egyéb források mellett nagy részben támaszkodtam a Pénzügyi és Tőzsdei Almanachokban megjelent banki anyagokra (leírásokra és pénzügyi adatokra). Ugyancsak sok helyen jelennek meg az Állami Pénzügyi és Tőkepiaci Felügyelet, a Pénzügyi Szervezetek Állami Felügyelete és az MNB jelentéseiben, valamint általuk közzétett információk, illetve adatok. Emiatt az anyagban ezekre a továbbiakban külön nem hivatlozom. 
A ma is müködő intézmények esetében bemutatásuk sorrendjét a bankszektor tárgyalt időszakbeli fejlődésének nagyobb szakaszai és a bankoknak a magyar piacra történő belépése határozzák meg, míg a már nem müködő vagy most nem Bankszövetség-tag intézményekről az utolsó fejezetben esik szó.

\section{1. táblázat}

Banki rangsorok (1989-2017) ${ }^{24}$

\begin{tabular}{|c|c|c|c|c|c|c|c|c|}
\hline & 1989 & 1990 & 1991 & 1992 & 1993 & 1994 & 1995 & 1996 \\
\hline 1 & OTP & OTP & OTP & OTP & OTP & OTP & OTP & OTP \\
\hline 2 & MHB & MHB & MHB & MHB & MHB & МHB & MKB & Postabank \\
\hline 3 & MKB & MKB & MKB & $\mathrm{K} \& \mathrm{H}$ & $\mathrm{K} \& \mathrm{H}$ & $\mathrm{MKB}$ & $\mathrm{CIB}$ & $\mathrm{K} \& \mathrm{H}$ \\
\hline 4 & $\mathrm{~K} \& \mathrm{H}$ & $\mathrm{K} \& \mathrm{H}$ & $\mathrm{K} \& \mathrm{H}$ & MKB & MKB & $\mathrm{K} \& \mathrm{H}$ & Postabank & MKB \\
\hline 5 & $\mathrm{BB}$ & $\mathrm{BB}$ & $\mathrm{BB}$ & $\mathrm{BB}$ & $\begin{array}{l}\text { Posta- } \\
\text { bank }\end{array}$ & Postabank & $\mathrm{K} \& \mathrm{H}$ & CIB \\
\hline 6 & CIB & CIB & $\begin{array}{l}\text { Posta- } \\
\text { bank }\end{array}$ & $\begin{array}{l}\text { Posta- } \\
\text { bank }\end{array}$ & $\mathrm{BB}$ & $\mathrm{BB}$ & MHB & MHB \\
\hline 7 & Citibank & $\begin{array}{l}\text { Posta- } \\
\text { bank }\end{array}$ & CIB & CIB & CIB & CIB & $\mathrm{BB}$ & $\mathrm{BB}$ \\
\hline 8 & $\begin{array}{l}\text { Posta- } \\
\text { bank }\end{array}$ & IEB & $\begin{array}{c}\text { Takarék- } \\
\text { bank }\end{array}$ & $\begin{array}{c}\text { Takarék- } \\
\text { bank }\end{array}$ & IEB & IEB & $\begin{array}{l}\text { Unic- } \\
\text { bank }\end{array}$ & $\begin{array}{l}\text { Credit- } \\
\text { anstalt }\end{array}$ \\
\hline 9 & $\begin{array}{c}\text { Takarék- } \\
\text { bank }\end{array}$ & $\begin{array}{c}\text { Takarék- } \\
\text { bank }\end{array}$ & Citibank & IEB & $\begin{array}{l}\text { IBUSZ } \\
\text { Bank }\end{array}$ & $\begin{array}{l}\text { Unic- } \\
\text { bank }\end{array}$ & $\begin{array}{l}\text { Credit- } \\
\text { anstalt }\end{array}$ & Unicbank \\
\hline 10 & IEB & $\begin{array}{l}\text { Unic- } \\
\text { bank }\end{array}$ & IEB & $\begin{array}{l}\text { Mező- } \\
\text { bank }\end{array}$ & $\begin{array}{c}\text { Takarék- } \\
\text { bank }\end{array}$ & $\begin{array}{l}\text { Credit- } \\
\text { anstalt }\end{array}$ & ING & Mezőbank \\
\hline 11 & $\begin{array}{c}\text { Agro- } \\
\text { bank }\end{array}$ & $\begin{array}{l}\text { Agro- } \\
\text { bank }\end{array}$ & $\begin{array}{l}\text { IBUSZ } \\
\text { Bank }\end{array}$ & $\begin{array}{l}\text { IBUSZ } \\
\text { Bank }\end{array}$ & Citibank & Citibank & IEB & Citibank \\
\hline 12 & $\begin{array}{l}\text { Unic- } \\
\text { bank }\end{array}$ & $\begin{array}{l}\text { Credit- } \\
\text { anstalt }\end{array}$ & $\begin{array}{l}\text { Unic- } \\
\text { bank }\end{array}$ & $\begin{array}{l}\text { Unic- } \\
\text { bank }\end{array}$ & $\begin{array}{l}\text { Unic- } \\
\text { bank }\end{array}$ & $\begin{array}{c}\text { Takarék- } \\
\text { bank }\end{array}$ & Citibank & MFB \\
\hline 13 & $\begin{array}{l}\text { Mező- } \\
\text { bank }\end{array}$ & ÁÉB & $\begin{array}{l}\text { Credit- } \\
\text { anstalt }\end{array}$ & Citibank & $\begin{array}{l}\text { Mezö- } \\
\text { bank }\end{array}$ & ING & $\begin{array}{c}\text { Commerz- } \\
\text { bank }\end{array}$ & IEB \\
\hline 14 & ÁÉB & $\begin{array}{l}\text { Mező- } \\
\text { bank }\end{array}$ & $\begin{array}{l}\text { Mező- } \\
\text { bank }\end{array}$ & $\begin{array}{l}\text { Agro- } \\
\text { bank }\end{array}$ & $\begin{array}{l}\text { Agro- } \\
\text { bank }\end{array}$ & $\begin{array}{c}\text { Commerz- } \\
\text { bank }\end{array}$ & MFB & ING \\
\hline 15 & ÁVB & Citibank & $\begin{array}{l}\text { Agro- } \\
\text { bank }\end{array}$ & ÁÉB & $\begin{array}{l}\text { Credit- } \\
\text { anstalt }\end{array}$ & $\begin{array}{l}\text { Mezö- } \\
\text { bank }\end{array}$ & $\begin{array}{c}\text { Takarék- } \\
\text { bank }\end{array}$ & $\begin{array}{c}\text { Commerz- } \\
\text { bank }\end{array}$ \\
\hline
\end{tabular}

24 A rangsor az összes táblázatban szereplő információk, adatok készítése során a megfelelő évben az adott bankcsoporthoz tartozó, bankszektorbeli intézmények összesített adatai alapján alakult ki. 


\begin{tabular}{|c|c|c|c|c|c|c|c|c|}
\hline & 1997 & 1998 & 1999 & 2000 & 2001 & 2002 & 2003 & 2004 \\
\hline 1 & OTP & OTP & OTP & OTP & OTP & OTP & OTP & OTP \\
\hline 2 & $\mathrm{~K} \& \mathrm{H}$ & MKB & MKB & MKB & $\mathrm{K} \& \mathrm{H}$ & $\mathrm{K} \& \mathrm{H}$ & $\mathrm{K} \& \mathrm{H}$ & $\mathrm{K} \& \mathrm{H}$ \\
\hline 3 & MKB & $\mathrm{K} \& \mathrm{H}$ & CIB & CIB & MKB & MKB & MKB & MKB \\
\hline 4 & $\begin{array}{c}\text { Posta- } \\
\text { bank }\end{array}$ & CIB & $\mathrm{K} \& \mathrm{H}$ & $\mathrm{K} \& \mathrm{H}$ & CIB & CIB & CIB & CIB \\
\hline 5 & CIB & Postabank & ABN AMRO & Raiffeisen & HVB Bank & $\begin{array}{l}\text { HVB } \\
\text { Bank }\end{array}$ & $\begin{array}{c}\text { Raiffei- } \\
\text { sen }\end{array}$ & Erste \\
\hline 6 & $\begin{array}{c}\text { ABN } \\
\text { AMRO } \\
\end{array}$ & ABN AMRO & Postabank & $\mathrm{BB}$ & Raiffeisen & $\begin{array}{c}\text { Raiffei- } \\
\text { sen }\end{array}$ & \begin{tabular}{|l|} 
HVB \\
Bank \\
\end{tabular} & $\begin{array}{c}\text { Raiffei } \\
\text { sen }\end{array}$ \\
\hline 7 & BB & $\mathrm{BB}$ & $\mathrm{BB}$ & $\begin{array}{c}\text { Posta- } \\
\text { bank }\end{array}$ & Postabank & MFB & MFB & \begin{tabular}{|l} 
HVB \\
Bank \\
\end{tabular} \\
\hline 8 & $\begin{array}{c}\text { Raiffei- } \\
\text { sen } \\
\text { Unicbank }\end{array}$ & BA-CA & $\mathrm{BA}-\mathrm{CA}$ & ÁÉB & MFB & $\begin{array}{l}\text { Posta- } \\
\text { bank }\end{array}$ & Erste & MFB \\
\hline 9 & MFB & MFB & Raiffeisen & BA-CA & ÁÉB & Erste & \begin{tabular}{|l} 
Posta- \\
bank
\end{tabular} & $\mathrm{BB}$ \\
\hline 10 & $\begin{array}{l}\text { Credit- } \\
\text { anstalt }\end{array}$ & $\begin{array}{l}\text { Raiffeisen } \\
\text { Unicbank }\end{array}$ & ÁÉB & Citibank & $\mathrm{BB}$ & $\mathrm{BB}$ & $\mathrm{BB}$ & FHB \\
\hline 11 & ÁÉB & ÁÉB & Citibank & MFB & Citibank & $\begin{array}{l}\text { Citi- } \\
\text { bank }\end{array}$ & $\begin{array}{l}\text { Citi- } \\
\text { bank }\end{array}$ & $\begin{array}{l}\text { Citi- } \\
\text { bank }\end{array}$ \\
\hline 12 & Citibank & Citibank & MFB & Erste & Erste & ÁÉB & ING & ING \\
\hline 13 & ING & Erste & ING & $\begin{array}{c}\text { Hypo } \\
\text { Vereinsbank } \\
\end{array}$ & ING & ING & FHB & ÁÉB \\
\hline 14 & IEB & IEB & $\begin{array}{c}\text { Нypo } \\
\text { Vereinsbank } \\
\end{array}$ & IEB & IEB & IEB & ÁÉB & IEB \\
\hline 15 & $\begin{array}{l}\text { Mező- } \\
\text { bank }\end{array}$ & $\begin{array}{c}\text { Нypo } \\
\text { Vereinsbank }\end{array}$ & Erste & ING & $\begin{array}{c}\text { Commerz- } \\
\text { bank }\end{array}$ & $\begin{array}{c}\text { Taka- } \\
\text { rék- } \\
\text { bank }\end{array}$ & IEB & $\begin{array}{c}\text { Taka- } \\
\text { rék- } \\
\text { bank }\end{array}$ \\
\hline
\end{tabular}

\begin{tabular}{|c|c|c|c|c|c|c|c|c|}
\hline & $\mathbf{2 0 0 5}$ & $\mathbf{2 0 0 6}$ & $\mathbf{2 0 0 7}$ & $\mathbf{2 0 0 8}$ & $\mathbf{2 0 0 9}$ & $\mathbf{2 0 1 0}$ & $\mathbf{2 0 1 1}$ & $\mathbf{2 0 1 2}$ \\
\hline 1 & OTP & OTP & OTP & OTP & OTP & OTP & OTP & OTP \\
\hline 2 & K\&H & K\&H & K\&H & K\&H & K\&H & K\&H & Erste & Erste \\
\hline 3 & MKB & CIB & MKB & CIB & MKB & Erste & K\&H & K\&H \\
\hline 4 & CIB & MKB & CIB & MKB & Erste & MKB & MKB & MKB \\
\hline 5 & Erste & Erste & Raiffeisen & Raiffeisen & CIB & CIB & CIB & CIB \\
\hline 6 & Raiffeisen & Raiffeisen & Erste & Erste & Raiffeisen & Raiffeisen & Raiffeisen & Raiffeisen \\
\hline
\end{tabular}




\begin{tabular}{|c|c|c|c|c|c|c|c|c|}
\hline & $\mathbf{2 0 0 5}$ & $\mathbf{2 0 0 6}$ & $\mathbf{2 0 0 7}$ & $\mathbf{2 0 0 8}$ & $\mathbf{2 0 0 9}$ & $\mathbf{2 0 1 0}$ & $\mathbf{2 0 1 1}$ & $\mathbf{2 0 1 2}$ \\
\hline $\mathbf{7}$ & $\begin{array}{c}\text { HVB } \\
\text { Bank }\end{array}$ & $\begin{array}{c}\text { HVB } \\
\text { Bank }\end{array}$ & UniCredit & UniCredit & UniCredit & UniCredit & UniCredit & UniCredit \\
\hline $\mathbf{8}$ & MFB & MFB & MFB & MFB & MFB & MFB & MFB & MFB \\
\hline $\mathbf{9}$ & BB & BB & BB & BB & FHB & FHB & FHB & FHB \\
\hline $\mathbf{1 0}$ & FHB & Citibank & FHB & FHB & BB & BB & BB & BB \\
\hline $\mathbf{1 1}$ & Citibank & FHB & Citibank & Citibank & Citibank & Citibank & Citibank & Citibank \\
\hline $\mathbf{1 2}$ & ING & IEB & ING & $\begin{array}{c}\text { BNP } \\
\text { Paribas }\end{array}$ & $\begin{array}{c}\text { BNP } \\
\text { Paribas }\end{array}$ & $\begin{array}{c}\text { BNP } \\
\text { Paribas }\end{array}$ & $\begin{array}{c}\text { Volks- } \\
\text { bank }\end{array}$ & $\begin{array}{c}\text { Volks- } \\
\text { bank }\end{array}$ \\
\hline $\mathbf{1 3}$ & $\begin{array}{c}\text { Takarék- } \\
\text { bank }\end{array}$ & $\begin{array}{c}\text { Volks- } \\
\text { bank }\end{array}$ & $\begin{array}{c}\text { Volks- } \\
\text { bank }\end{array}$ & $\begin{array}{c}\text { Volks- } \\
\text { bank }\end{array}$ & $\begin{array}{c}\text { Volks- } \\
\text { bank }\end{array}$ & AXA & AXA & AXA \\
\hline $\mathbf{1 4}$ & IEB & $\begin{array}{c}\text { Takarék- } \\
\text { bank }\end{array}$ & IEB & ING & AXA & $\begin{array}{c}\text { Volks- } \\
\text { bank }\end{array}$ & $\begin{array}{c}\text { BNP } \\
\text { Paribas }\end{array}$ & $\begin{array}{c}\text { Takarék- } \\
\text { bank }\end{array}$ \\
\hline $\mathbf{1 5}$ & $\begin{array}{c}\text { Volks- } \\
\text { bank }\end{array}$ & ÁÉB & $\begin{array}{c}\text { Takarék- } \\
\text { bank }\end{array}$ & $\begin{array}{c}\text { Takarék- } \\
\text { bank }\end{array}$ & $\begin{array}{c}\text { Takarék- } \\
\text { bank }\end{array}$ & ING & ING & ING \\
\hline
\end{tabular}

\begin{tabular}{|c|c|c|c|c|c|}
\hline & $\mathbf{2 0 1 3}$ & $\mathbf{2 0 1 4}$ & $\mathbf{2 0 1 5}$ & $\mathbf{2 0 1 6}$ & $\mathbf{2 0 1 7}$ \\
\hline $\mathbf{1}$ & OTP & OTP & OTP & OTP & OTP \\
\hline $\mathbf{2}$ & K\&H & K\&H & UniCredit & UniCredit & K\&H \\
\hline $\mathbf{3}$ & Erste & UniCredit & K\&H & K\&H & UniCredit \\
\hline $\mathbf{4}$ & CIB & Raiffeisen & Raiffeisen & Erste & Erste \\
\hline $\mathbf{5}$ & MKB & Erste & MKB & MKB & Bank of China \\
\hline $\mathbf{6}$ & UniCredit & MKB & Erste & Raiffeisen & Raiffeisen \\
\hline $\mathbf{7}$ & Raiffeisen & CIB & CIB & CIB & MKB \\
\hline $\mathbf{8}$ & FHB & FHB & MFB & Bank of China & CIB \\
\hline $\mathbf{9}$ & MFB & MFB & BB & MFB & Takarékbank \\
\hline $\mathbf{1 0}$ & Citibank & BB & FHB & BB & MFB \\
\hline $\mathbf{1 1}$ & BB & Takarékbank & EXIM & EXIM & BB \\
\hline $\mathbf{1 2}$ & ING & Citibank & Bank of China & Citibank & EXIM \\
\hline $\mathbf{1 3}$ & Sberbank & EXIM & Takarékbank & FHB & Citibank \\
\hline $\mathbf{1 4}$ & Takarékbank & ING & Citibank & Takarékbank & Fundamenta \\
\hline $\mathbf{1 5}$ & EXIM & Sberbank & ING & ING & ING \\
\hline
\end{tabular}




\subsection{Rendszerváltó bankok (1988-ig) ${ }^{25}$}

\subsubsection{OTP Bank Csoport $(27,2 \%)^{26}$}

Az OTP Bank Csoport a kétszintű bankrendszer kialakítása idején meglévő, piacvezető pozícióját az elmúlt három évtizedben sikeresen megőrizte, belső, organikus fejlődésével - amelynek során kevésbé vett részt nagyobb horderejű hazai bank- vagy portfólióvásárlásokban, illetve eladásokban - a magyar bankszektor vezető bankja maradt, és a 2000-es évektől folyamatos régiós akvizíciós tevékenységével diverzifikált, stabil nemzetközi bankhálózatot hozott létre.

Az Országos Takarékpénztár Nemzeti Vállalatot 1949-ben hozták létre lakossági takarékbetét gyüjtésre és ebből elsősorban az állam hitelezésére. Tevékenysége folyamatosan bővült más lakossági szolgáltatásokkal (először akció jellegű, majd kiterjedtebb lakossági hitelezéssel, 1957-től szerencsejáték-szervezéssel, 1964-től lakossági valuta- és devizaügyletekkel), majd 1971-től a tanácsok (később önkormányzatok) pénzügyeivel, 1983-tól banki értékpapírok kibocsátásával. A vállalati pénzügyi szolgáltatások nyújtására a jogosítványt 1989-ben, a külkereskedelemmel összefüggő pénzügyek bonyolítására 1990-ben szerezte meg.

1990-ben alakult át 100 százalékos állami tulajdonú részvénytársasággá, ennek során a nem banki tevékenységek jó részét leválasztották róla.

Tőkehelyzete nem tette szükségessé részvételét a hitel- és bankkonszolidációban, így már 1992-től elindulhatott a tulajdonosi szerkezet oldása, amely azonban az első években nem érintette az állam többségi tulajdonát. A banknak a lakossági piacon betöltött kulcspozíciója miatt a szakmai befektetőknek történő privatizálással összefüggésben felmerült gazdasági-politikai aggályok ${ }^{27}$ hatására 1995-ben csak kisebbségi pakettjét szerezhették meg külföldi befektetők (névérték feletti 120 százalékos áron). Ekkor a bank egyharmadát értékesítették belföldi és külföldi befektetőknek, 6 százaléka került a bank alkalmazottaihoz és 25 százaléka maradt az állam kezében, majd a részvényeket bevezették a tőzsdére. Az „államtalanítást” fokozatosan, 1999-ig fejezték be, azonban az állam részére 1 db szavazatelsőbbségi részvényt még 2007-ig fenntartottak.

A hazai cég hálójának kiépítése a részvénytársasággá alakulás és profiltisztítás során már 1990-ben elindult, az ingatlanberuházásra, -kezelésre szakosodott leánycége azóta is támogatja a banki tevékenységét. Ebben az expanzióban az első jelentősebb lépés az 1988-ban a K\&H Bank által alapított, elsősorban autófinan-

25 Alapításuk időpontja szerint a következő bankok is ebbe a csoportba tartoznak, azonban beolvadásuk, átalakulásuk, illetve megszűnésük okán más címen tárgyalom ezeket: ÁÉB, Innofinance Merchant Bank, Ybl Bank, Iparbankház, Dunabank.

26 A továbbiakban a bankok neve mögött a 2017. évi mérlegföösszeg alapján számított piaci részesedések szerepelnek.

27 L. VÁRHEgYi (1998) 
szírozásra szakosodott Merkantil Bank 1995-ös felvásárlása volt. 1997-ben megalapította szakosított hitelintézetét, az OTP Lakás-takarékpénztárat, majd 2002-ben a lakáshitelezési boom kiaknázására létrehozta az OTP Jelzálogbankot.

Az organikus fejlődés mellett az OTP Bank külföldi terjeszkedése is hozzájárult pozíciói megtartásához. A térségbeli expanzió 2002-ben indult a szlovákiai bankvásárlással, amelyet a közép- és kelet-európai bankakvizíciók sora követett: Bulgáriában 2003-ban, Romániában 2004-ben, Horvátországban 2005-ben, Szerbiában, Ukrajnában, Oroszországban és Montenegróban 2006-ban jelent meg, és egyes országokban több akvizíciót is végrehajtott.

Az akvizíciók sorát egyetlen banki érdekeltségének értékesítése tarkította, 2008ban a bank eladta a leánybiztosítóját a francia Groupama S.A.-nak, azonban az üzleti kapcsolat fennmaradt a két intézmény által kötött, hosszú távú együttműködési megállapodással. Az üzlet eredményeként a vételár és a bank saját eredményei elegendőek voltak akkori tókehelyzete stabilizálására, így az állami mentőövnek csak a devizafinanszírozási forrásait vette igénybe. Ez a hitelezési aktivitásával összefüggő vállalásokkal és az FB-be delegált állami taggal járt, ezen kötelezettségek alól a hitel gyorsított visszafizetésével 2010-ben szabadult.

\subsubsection{K\&H Bank Csoport (8,9\%)}

Az Országos Kereskedelmi és Hitelbankot a kétszintủ bankrendszer kialakításakor alapították, és az MNB agrár, élelmiszeripari, belkereskedelmi és idegenforgalmi cégportfólióját örökölte. Indulásakor 75 százalékos állami részvétel mellett 25 százalékban a legfontosabb nagyvállalati adósi kör volt a tulajdonosa. Müködésének korai szakaszában több szakosított bankot is alapított, 1988-ban a Merkantil Bankot, amelyet 1995-ben az OTP-nek értékesített, 1990-ben a Portfólió Bankot, amelyet a konszolidáció során beolvasztott, és 1991-ben a Kvantum Bankot, amely 200o-ben pénzügyi vállalkozássá alakult át. 1993-ban megvásárolta az alapítóitól (IBUSZ és ÁB Aegon) az IBUSZ Bankot ${ }^{28}$, amelyet a bankkonszolidációt követően 1996-ban beolvasztott.

Részt vett a hitelkonszolidációban, a bankkonszolidáció során csaknem 40 milliárd forintnyi alaptőke-emelésben, illetve alárendelt kölcsöntőke-juttatásban részesült.

Az állami nagybankok közül a legkésőbb, 1997-ben kezdődött meg a privatizációja. Ennek első lépéseként az EBRD alárendelt kölcsöntőkével erősítette meg a tőkehelyzetét, amit a privatizációs tender lezárultát követően részvénnyé konvertáltak. A privatizációs tenderen a belga Kredietbank és az ír Irish Life biztosító konzorciuma 10 százalékos kisebbségi részesedést szerzett, majd az általuk végrehajtott tőkeemelést követően lett a $K \& H$ összességében többségi külföldi

28 Érdekesség: elsőként az IBUSZ Bank bocsátott ki betéti kártyát. 
tulajdonú vegyesbank. A Kredietbank bankvásárlását követően kialakított KBC Bank és Biztosítási Csoport 1999-ben csaknem 8o százalékos többségi tulajdont szerzett a bankban.

2001-ben egyesült a K\&H és az ABN AMRO Magyar Bank, a létrejött bank tulajdonosa a többi szakmai befektető kivásárlásával 59 százalékban a KBC, 40 százalékban a holland ABN AMRO lett. A bankegyesülést követően időszakban 4 év kivételével (2011-12 és 2015-16) az OTP csoport mögött a második legnagyobb bankcsoport volt.

2007-től kizárólagos tulajdonosa a KBC. ${ }^{29}$

\section{Magyar Hitel Bank - ABN AMRO Magyar Bank}

Az MHB-t ugyancsak a kétszintű bankrendszer kialakítása keretében alapították, és az MNB ipari, közlekedési és szolgáltatási portfólióját örökölte. 1989-1994 között az OTP mögött a második legnagyobb mérlegföösszegű bank volt. Két vegyesbank, az MHB-Daewoo Bank és a Leumi Hitel Bank Rt. alapításában is részt vett, a bankkonszolidáció időszakában előbbit értékesítette, utóbbit a betétállomány átvételét és kivásárlását követően a reorganizációs kísérlet meghiúsulása után végelszámolták. ${ }^{30} \mathrm{~A}$ bankpiacon a konszolidációt megelőző időszak alatt folyamatosan vesztett teret (piaci részesedése 19 százalékról 10 százalékra esett vissza), majd a hitelkonszolidáció tovább erodálta az eszközeit, így piaci részesedése 5 százalék környékére esett vissza a privatizáció időpontjáig.

A bankkonszolidáció során csaknem 60 milliárd forintos tőke és 6 milliárdos alárendelt kölcsöntőke-injekcióval mentették ki. ${ }^{31}$ A konszolidációt követően, 1996ban a részvények csaknem 90 százalékát értékesítették a holland ABN AMROnak a részvények névértékének 225 százalékán. ${ }^{32} \mathrm{Az}$ anyabankja több lépcsőben jelentős tőkeemelést is végrehajtott, majd a következő évben az itt lévő leánybankjával (1. alább) összeolvasztotta.

\section{ABN AMRO Bank}

1993-ban zöldmezős beruházással indította el kizárólagos tulajdonlással a holland ABN AMRO. Önálló működése során megnégyszereződött a piaci részesedése, ami azonban az MHB utódbankjával történt összeolvadáskor sem érte el az 1 százalékot.

29 Érdekesség: a K\&H Bank 2002-ben hazánkban elsőként hozott forgalomba mikrochipes bankkártyát.

30 ÁSZ (1996)

31 ÁBEL-SZAKADÁt (1997)

3214 milliárd forint vételáron, 1. ÁBEL-SZAKADÁt (1997). 


\subsubsection{Erste Bank Csoport (6,7\%)}

A Mezőbankot 1986 végén 1400 mezőgazdasági szövetkezet alapította fejlesztési pénzintézetként. A bank 1989 elejétől kereskedelmi bankként működött középbanki méretben. 1993-ra elvesztette a saját tőkéjét, majd részt vett a hitel- és bankkonszolidációban, így 1995-re az állam csaknem 90 százalékos tulajdont szerzett a bankban. A konszolidációig tartó történetében a 10-15. helyen szerepelt a mérete alapján. 1996-ban beolvasztotta a hasonló profilú, 1987-ben alakult, 1995-ben csődbe jutott és szanált Agrobankot, amivel az addig 1 százalék körüli piaci részesedése megduplázódott, azonban így sem tudott a 10. helynél előbbre lépni.

A privatizáció során az osztrák Erste Group 1997-ben szerezte meg a részvények 84 százalékát, majd a következő években tőkeemelésekkel tovább növelte részesedését (1998-ban 94 százalékra, 2001-ben, majd 2002-ben csaknem 100 százalékra). A tulajdoncserét követő évben a bank nevet változtatott, felvéve a bankcsoportja elnevezését.

Az új tulajdonossal a bank organikus fejlődéssel közel 4 százalékra emelte a részesedését a következő években.

2003-ban az anyabankja megvette a magyar államtól a Postabankot, és egy évvel később beolvasztotta a magyar bankjába, amivel az bekerült az öt legnagyobb magyar bank közé, 7 százalékot meghaladó piaci résszel. A piaci átlagot meghaladó bővülése 2012-ig töretlen volt, csaknem 10 százalékot elérő részesedése ezt követően fokozatosan csökkent 2015-ig 6 százalékra, ami újabb fordulópontnak látszik.

\section{Postabank és Takarékpénztár}

A 9o-es évek egyik ikonikus bankja, amelynek a fejlődése az 1997-es betétesi rohamot követően roppant meg, amit állami bábáskodás mellett folyó, hosszas konszolidáció és portfóliótisztítás követett.

1988-ban alapították kisebbségi külföldi tulajdonnal müködő vegyesbankként a Magyar Posta részvételével azért, hogy annak hálózatát kiaknázzák bankszolgáltatások céljára.

Fejlődése 1996-ig töretlen volt, akkor a bankok rangsorában elérte a második helyet 8,5 százalékos piaci részesedéssel (ez 1989-ben csupán 1,4 százalék volt). A privatizációból megerősödve kikerülő versenytársak és hibás üzletpolitikai döntések következtében a fejlődése megtört, majd az 1997-es nagy betétkivonás eredményeként tőkéjét elvesztette, és 1998-ban állami konszolidációra szorult. Ezt követően addigi piaci súlya fokozatosan 3 százalékra csökkent 2003-ig, az Erste általi, ismételt privatizációjáig. 


\section{PK Bank}

Jogelődje, a Pénzintézeti Központ 1916-ban alakult meg szövetkezeti formában, elsődlegesen bankfelügyeleti műveletek ellátására. Hatósági feladatai miatt az államosítást követően is tovább működött egyes pénzügyi, hatósági tevékenységek végzésével. 1992-ben alakult részvénytársasággá, majd 1995-ben banki jogosítványt kapott, és Pénzintézeti Központ (PK) Bank néven folytatta tovább a tevékenységét. Ugyanebben az évben olvasztotta magába az Investbankot (amely 1991-ben alakult, 1993-ban beolvasztotta az 1980-ban létrejött és 1988 óta bankként működő Innofinance Merchant Bank eszközeit). A Polgári Bankot ${ }^{33}$ 1997-ben vásárolta meg az államtól. Ugyanebben az évben privatizálták egy, az Atlasz Biztosító által vezetett és a Postabank által finanszírozott magyar pénzügyi konzorciumnak, azonban a részesedést még abban az évben átvette a Postabank. Csak ezt követően olvadt bele a Polgári Bank, illetve váltott nevet Polgári Kereskedelmi (PK) Bankra. Az anyabank 1997-es megroppanása azonban a bank hosszas stagnálását idézte elő. Végül 2001-ben állományát átvette a Postabank, az intézmény pedig banki jogosítványait visszaadva, 2002-ben alakult át pénzügyi vállalkozássá, majd 2004-ben a Postabank értékesítette.

\subsubsection{Raiffeisen Bank $(6,2 \%)$}

1986-ban Unicbank néven alapították, magyar részről az OTP, a Központi Váltó és Hitelbank és nem mezőgazdasági szövetkezetek, továbbá az osztrák Raiffeisen, a washingtoni IFC és a német DG Bank 15-15\%-os részesedésével. Utóbbit a Raiffeisen 1990-ben kivásárolta. Fejlődésének első időszakában a vállalati piacon működött jellemzően budapesti jelenléttel. Mérsékelt súlyt képviselt a piacon, a 10-12. helyet foglalta el a bankok rangsorában 1 százalék körüli részesedéssel. Megtorpanását követően 1991-92-ben az osztrák Raiffeisen további kivásárlásokkal meghatározó többségi tulajdonossá vált, majd a bank nyitott a vidék irányába, amivel 2-3 százalékra növelte a részesedését, és bekerült a legjobb 10 bank közé. A többségi tulajdon megszerzése és bővítése a magyar banknál névváltozással is járt, 1997-től Raiffeisen Unicbank, 1999-től Raiffeisen Bank lett. Az újabb lépcsőfokot a névváltozással egy időben a banki tevékenység lakossági irányba történő 1999-es kiterjesztése jelentette. Ennek eredményeként a 2000-es évek elejétől fokozatosan emelte piaci részesedését, ami az évtized közepétől 7-8 százalék körüli szinten stabilizálódott, ezzel a bank folyamatosan az 5-6. helyen volt a banki rangsorban. A Raiffeisen az egyetlen nagybankunk, amely a bővülését szinte kizárólag organikus fejlődéssel, banki akvizíció nélkül érte el.

33 Az előzményeket lásd a Budapest Bankról szóló részben. 


\subsubsection{MKB (5,9\%)}

1950-ben alapították a monolit bankrendszer külkereskedelmi pénzügyi tevékenységét, elsősorban a nemzetközi fizetési forgalmat támogató részeként.

A kétszintű bankrendszer kialakításakor kereskedelmi banki jogosítványokat kapott, és 2012-ig rendre a banki rangsorban dobogós, illetve az azt követő helyen végzett. A bank fejlődése zömében organikus volt, jelentős akvizíciót ritkán hajtott végre. Talán egyetlen említésre méltó bankvásárlása 2003-ban a Konzumbank megszerzése és beolvasztása. Az 1980-as évek végi 15 százalék körüli piaci részesedése a konszolidáció időszakában csökkent arra a 8-9 százalék körüli szintre, amelyet 2011-ig megtartott, azonban ezt követően piaci súlya fokozatosan csökkenni kezdett, egészen a mai szintig.

Az öt állami nagybank közül elsőként az MKB privatizációja indult el. A német Bayerische Landesbank a részvények 25, az EBRD 16 százalékát szerezte meg 1994 végén, illetve 1995 közepén. Az ezt követő évben tőkeemeléssel és a magyar tulajdonosok kivásárlásával a BLB többségi tulajdont szerzett, majd évről évre növelte a részesedését a 2000-es évek közepéig. A 2008-as pénzügyi válságot követően megroppant BLB állami pénzügyi segítség fejében az Európai Bizottsággal 2012ben megállapodást kötött, aminek a következtében más érdekeltségek mellett meg kellett szüntetnie részesedését az MKB-ban is (ettől kezdve mutatkozott meg számokban a bank piaci térvesztése). Így 2014-ben ismét magyar állami tulajdonba került a bank, majd reorganizációját követően 2016-ban magyar hátterű magánbefektetők lettek a részvényesei.

\section{Konzumbank}

A bankot 1986-ban alapították, főként ÁFÉSZ-ek részvételével. Részt vett a hitelkonszolidációban, és bár egy kisebb összegű tőkeemelést végrehajtott benne az állam, azonban valódi bankkonszolidációs lépésekre a Konzumbank esetében nem volt szükség. 1995-ben a Magyar Befektetési és Fejlesztési Bank (ma MFB) tőkeemelés útján többségi tulajdonosává vált. 1997-ben a bankba olvadt az 1988-ban az Országos Műszaki Fejlesztési Bizottságot támogató ipari fejlesztési bankként létrehozott, majd 1992-től kereskedelmi bankként üzemelő Corvinbank.

\subsubsection{CIB Bank $(4,8 \%)$}

A bank alapító elődje, a Közép-európai Nemzetközi Bank Rt. (CIB) 1979-ben jött létre mint dolláralapon müködő devizabank. Tevékenységét 1995-ig a banki jogosítványai alapján kizárólag devizában végezte. A bank részvénytulajdonosai a Magyar Nemzeti Bank (34 százalék) mellett 6 vezető európai és japán bankház voltak, egyenlő részesedéssel. 
A pénzügyi piac megnyílásával ügyfélkörének forintmüveletek végzésére is igénye mutatkozott, ezért a pénzintézet ebből a célból 1988-ban megalapította leánybankját, a CIB Hungária Bankot.

1997-ben szabályozási okokból az MNB eladta részesedését, ennek során egyik részvényese, a Banca Commerciale Italiana Csoport kivásárolta a többi részvényest a japán befektető kivételével, így 95 százalékos részesedést szerzett, majd ezt 1999-ben ezt is megszerezve növelte a tulajdonrészét 100 százalékra.

A devizaliberalizáció kiteljesedése szükségtelenné tette a pénznemek mentén szétválasztott működési struktúrát, így 1998 év elején a leánybankot beolvasztották.

A banki struktúrában a következő változás az Inter-Európa Bank 2008-ban végrehajtott beolvasztása, amely az anyabankok (Banca Intesa Csoport és Sanpaolo IMI) 2007-es fúziójának logikus következménye volt.

A bank fejlődése az időszak alatt egészen a 2008-tól induló válságig töretlen (a hitel és bankkonszolidációban sem volt érintett). A 2010-es évektől a válság negatív hatása a bank eszközeire és részesedésére jelentkezett a számaiban is. A piaci részesedését közel 4 százalékról folyamatos, átlagot meghaladó bővüléssel az 1990-es évek végére megduplázta, majd folyamatosan 8-9 százalék körüli szinten tartotta egészen 2012-ig, ami ezt követően folyamatos csökkenéssel érte el a mai szintet.

\section{Inter-Európa Bank}

1981-ben alapította az MKB és több külkereskedelmi állami vállalat Interinvest Külkereskedelmi Fejlesztési Hitelintézet néven, majd viszonylag korán, már 1985ben banki jogosítványokat kapott, ideértve a betétgyüjtést is. 1989-ben a San Paolo di Torino Bank 23 százalékos kisebbségi részesedése mellett vegyesbankká alakult. A bankok közül elsőként, 1994-ben vezették be a tőzsdére. Ezt követően fokozatosan vált többségi tulajdonossá az anyabank. 2003-ban ennek egy jelentős állomása volt a nyilvános ajánlattétel, amellyel az anyabank 86 százalékos részesedést szerzett. A bank a fennállása időszakában szinten tartotta 1-2 százalék közötti piaci részesedését, ez a 90-es évek első felében a 8. helyre is elegendő volt, míg az újonnan belépők és a verseny hatására a 2000-es években éppen befért az első 15 bank közé.

\subsubsection{Budapest Bank (2,9\%)}

A Budapest Bankot is a kétszintű bankrendszer kialakításakor alapították, az MNB infrastrukturális és bányászati cégportfólióját kapta meg. Az akkori bankcsoportba további bankokat alapított, 1989-ben leánybankként leválasztotta a $R e$ álbankot, amelyet később, 1993-ban értékesített hazai magánbefektetőknek. Az értékesítéssel egy évben megalapította a Polgári Bankot, amely átvette a felszá- 
molás alá került $Y b l$ Bank banküzemét és kötelezettségeit ${ }^{34}$, de ezt a privatizációs szerződésben lévő opció alapján az új tulajdonos (GE) az államnak értékesítette 1996-ban.

A bankkonszolidáció során a bank alárendelt kölcsöntőke-juttatásban részesült a privatizáció sikeres lebonyolítása érdekében.

A konszolidációt követően 1995 decemberében az amerikai General Electric Capital és az EBRD megvásárolta a Budapest Bank részvényeinek 27,5, illetve 32,5 százalékát. Opciós jogát gyakorolva, tulajdonrésze növelésével a GE 2001-ben a bank csaknem 100 százalékos tulajdonosává vált.

A bank az 1980-as évek végén még az 5. legnagyobb volt csaknem 8 százalékos piaci részesedéssel, ami fokozatosan erodálódott a 2000-es évek elejéig 3 százalék körüli szintre, és ott stabilizálódott.

2015 elején az MFB tulajdonában álló Corvinus Zrt. megvásárolta a GE Capitaltól a bank teljes részvényállományát 700 millió USD-ért.

\subsubsection{Citibank (1,7\%)}

1985-ben hozták létre zöldmezős beruházással; ez az intézmény volt az első valódi kereskedelmi banki jellegű pénzügyi szolgáltatások végzésére létrehozott, többségi külföldi tulajdonú vegyesbank. 1992-ben a Citibank Overseas kivásárolta a kisebbségi magyar résztulajdonost, és a bank kizárólagos tulajdonosává vált. Az első tíz év során a vállalati szegmensben működött a nagyvállalati kört megcélozva. 1995-ben indította el a lakossági szolgáltatásokat, ezzel lépte át a 2 százalékos piaci részesedést. 1998-ban felvásárolta az Európai Kereskedelmi Bankot, aminek a tevékenységét beolvasztva indult el a kkv-üzletága. Ennek eredményeként 2,5 százalékra nőtt a részesedése. 2000-ben megvette az ING Bank kártyaüzletágát amelyet az ING eredetileg a Dunabanktól vett át 1996-ban -, valamint annak kkvüzletágát és fiókhálózatát, ezzel országos lefedettséggel folytatta a tevékenyégét, aminek a segítségével további 1 százalékkal növelte a piaci súlyát. Ezt követően azonban lassú, hullámzó visszaesés következett be a piaci súlyában, a mélypontot a 2009-es fiókteleppé alakulás jelentette, amikor 2 százalék alá esett a részesedése. Egy rövid felívelést követően 2017-ben hosszas előkészítés után az Erste Banknak eladta a lakossági üzletágát, ezzel részesedése ismét 2 százalék alatti lett.

\subsubsection{Gránit Bank $(0,9 \%)$}

1985-ben hozták létre az Általános Vállalkozási Bankot szakosított pénzintézetként. 1988-ban bankká alakult, majd a legelsők között jutott csődbe egy váltóügylet miatt 1992-ben. A bajba jutott bankot a Westdeutsche Landesbank vásárolta ki, csaknem 60 százalékos részesedést szerezve. A következő évben az anyabank

34 Magyar Parlament (1997) 
a pénzintézet csaknem kizárólagos tulajdonosává vált (100 százalékos tulajdonjogát csak 200o-ben szerezte meg), ekkor a bank nevet változtatott WestLB Hungariára. A 2009 végéig tartó időszakban csak a 2000-es évek fordulóján érte el az 1 százalékos piaci részesedést, majd 2002-től folyamatosan teret vesztett. 2010 elején egy rövid időszakra a Wallis tulajdonába került, és nevet váltott Milton Bankra. Ekkorra a mérete alig haladta meg a 4 bázispontot. Még ennek az évnek a közepén vette át a bankot a Magyar Tőketársaság Zrt., majd több tulajdonos bevonását követően, 2015-ben a részesedését az EPM Kft.-nek értékesítette. A bank az új korszakában gyakorlatilag nulláról folyamatosan bővítette a tevékenységét, és elérte az 1 százalékos piaci részesedést.

\subsection{Korai bankalapítások (1989-94)}

\subsubsection{UniCredit Bank Csoport $(8,7 \%)$}

A Creditanstalt Rt.-t 1990-ben képviseleti irodája bankká alakításával hozta létre osztrák állami többségi részesedéssel működő anyabankja a Budapest Bank 25 százalékos kisebbségi részesedése mellett. Egy évvel később anyabankja kivásárolta a $\mathrm{BB}$ részesedését, és a bank kizárólagos tulajdonosává vált. Miután az osztrák állam az anyabankjában lévő részesedéseit 1997-ben eladta az osztrák Bank Austriának és a két bank a rákövetkező évben fuzionált, ennek hatásaként 1998-ban a magyar bank is a BA-CA (Bank Austria Creditanstalt) nevet vette fel. A bank ebben az időszakban organikus fejlődéssel folyamatosan bővült, és az évtized végére 4 százalékos piaci részesedést ért el, ezzel a bankok rangsorában a 8. helyre jutott.

A magyar Hypo Bankot azonos nevü német tulajdonosa 100 százalékos részesedéssel hozta létre 1993-ban, ezzel a német univerzális nagybankok közül elsőként lépett a magyar piacra. Az anyabank magyarországi tevékenységének támogatására 1998-ban hozta létre a jelzálogbankját. Még ugyanebben az évben az anyabank egyesült a Bayerische Vereinsbankkal, aminek a következtében a magyar kereskedelmi bankja felvette a HypoVereinsbank, jelzálogbankja a HVB Jelzálogbank nevet. A csoport az ezredfordulóig középbanki szintre jutott, a két intézmény együttesen 2,5 százalék alatti piaci részesedést birtokolt.

200o-ben a német anyabanki csoport megszerezte az osztrák anyabanki csoportot, összeolvasztásuk azonban nem történt meg, hanem az osztrák csoport lett a régiós piacok felelőse. Ennek eredményeként Magyarországon a HypoVereinsbankot átvette a BankAustria AG, amely a két magyar leánybankot összeolvasztotta, így

35 Alapításuk időpontja szerint a következő bankok is ebbe a csoportba tartoznak, azonban beolvadásuk, átalakulásuk, illetve megszűnésük okán más címen tárgyaljuk azokat: Ingatlanbank, Reálbank, Európai Kereskedelmi Bank, Portfólió Bank, Leumi Hitel Bank, IBUSZ Bank, Kvantum Bank, Nomura Bank, Crédit Lyonnais Bank (későbbi Crédit Agricole Fióktelep), Rákóczi Bank, Polgári Bank, ABN AMRO Bank, HypoVereinsbank, BKD Bank (későbbi BNP Dresdner, BNP Paribas, illetve Premier Bank), IC Bank (későbbi Banco Popolare), ING Bank (jelenleg fióktelep). 
létrejött a HVB Bank Hungary, amely a fúzió eredményeként az 5. legnagyobb bank lett, közel 6 százalékos piaci részesedéssel.

Paradox módon, bár részesedése némileg növekedett, mégis két helyet lépett viszsza a 2007-ig tartó időszak során.

2005-ben az anyaintézmények körében ismételt fúzió történt, ennek következtében a magyar csoporttagok 2007-ben felvették a UniCredit nevet.

A válság időszakában a csoport rövid ideig teret veszített, azonban 2010-től is növelni tudta részesedését, 2015-től 9 százalék körüli szintre érve, ezzel a banki ragsorban a 2-3. helyen tartózkodott.

\subsubsection{Takarékbank Csoport (4,6\%)}

A Magyar Takarékszövetkezeti Bankot takarékszövetkezetek hozták létre 1989ben. Az alapítók célja az volt, hogy forrásaik felhasználására versenyképes, általuk is befolyásolható intézmény jöjjön létre, mivel a funkciót korábban ellátó OTP esetében nem látták biztosítottnak ezeket a követelményeket. A takarékszövetkezetek központi bankja funkciójának intézményesítését végül a takarékszövetkezetek integrációját létrehozó szerződés biztosította 1993-ban, amely az ennek megfelelő jogosítványokkal ruházta fel a bankot. A konszolidációt megelőző időszakban a bank erős középbankként üzemelt, 1993-ra azonban gyakorlatilag elvesztette a tőkéjét. Ennek következtében vett részt a hitel- és bankkonszolidációban, aminek az eredményeként az állam kétharmadnyi részesedést szerzett a bankban. A privatizációjáig tartó időszakban jelentősen leromlott a bank teljesítménye, eszközállománya lényegében stagnált, így piaci részesedése jelentősen visszaesett. Helyzete a 1997-es privatizációval és tőkeemeléssel rendeződött, ekkor a Németországban hasonló funkciót ellátó DG (későbbi DZ) Bank (amely 1990-ig a Unicbank tulajdonosa is volt) jelentős felár fizetésével 70 százalék feletti részesedést szerzett benne azzal a feltétellel, hogy a tulajdonosi körben kisebbségbe került, integrált takarékszövetkezetek a stratégiai döntésekben vétójogot biztosító aranyrészvényt kaptak. ${ }^{36}$

2003-ban a takarékszövetkezetek hároméves opciós szerződést kötöttek a főtulajdonossal, ennek alapján 2006-ig többségi részesedést szerezhettek a bankban. 2004ben ez is megtörtént, aminek az eredményeként 2005-re a bank 63 százaléka került takarékszövetkezeti kézbe, és a DZ Bank kisebbségi részvényessé vált. A fennmaradó, egyharmadnyi részesedését 2012-ben értékesítette az MFB-nek. A német tulajdonos irányítása sem segítette elő, hogy a középbanki szerepkörből kitörjön a bank, 2 százalékos piaci részesedést sem sikerült ebben az időszakban elérnie.

Az ambiciózus tervekkel létrehozott, új takarékszövetkezeti integráció (SZHISZ) indulását követően jelentős tulajdonosi összefonódás alakult ki a bank, a Magyar

36 Ábel-Szakadát (1997) 
Posta és az FHB Csoport részvételével. A bank némileg nagyobb lendületet kapott, és elérte a 2,5 százalékos részesedést. 2016 végén a Takarék Csoport többségi tulajdont szerzett az FHB Csoportban, végrehajtotta az átszervezését, amely a különböző csoporttagok profiltisztításával is járt, így jelenleg már a 9. legnagyobb intézmény, amelynek piaci súlya csaknem 5 százalékhoz közelít.

\section{FHB Jelzálogbank és FHB Kereskedelmi Bank}

Az FHB Jelzálogbankot 1997-ben, a jelzálog-banktörvény megszületését követően alapították 37 százalékos állami és 48 százalékos MFB-részvétellel, valamint további három bank tulajdonlásával az érintett piacok (hosszú hitel, kötvény és ingatlan) fejlesztésének céljával. Működése korai éveiben tevékenységével elősegítette a kormányzat lakásfejlesztéssel összefüggő terveinek a végrehajtását, és 2001-től sikeresen használta ki a támogatott lakáshitelek gyors felfutását, ezzel 2004-re 2,5 százalékos piaci részt ért el.

2003-ban indult el a privatizációja tőzsdei bevezetéssel egybekötve, azonban az állam ekkor még mindig többségi tulajdonosa maradt. A Jelzálogbank 2006-ban létrehozta az FHB Kereskedelmi Bankot. Ezzel párhuzamosan stratégiai partnerségre lépett az Allianzzal, amely megvásárolta a Dresdner Bank kiürített társaságát annak banki jogosítványaival együtt, és elindította az Allianz Bankot. A partnerség keretében végül az FHB Jelzálogbank megvásárolta az Allianz Bankot, amely 2011-ben beolvadt az FHB Kereskedelmi Bankba. Ebben az időszakban az intézmény 2014-re további 1 százalékponttal növelte összességében a piaci részesedését. 2015 hozott fordulatot a fejlődésben, utána a pénzintézet súlya folyamatosan csökkent a mai szintre.

\subsection{3. $\operatorname{MFB}(3,4 \%)$}

A Magyar Befektetési és Fejlesztési Rt.-t 1991-ben alapították állami hátterü szervezetek. Szakosított pénzintézeti jogosítványait csak 1993-ban szerezte meg, ekkortól üzemel befektetési, fejlesztési bankként, szerepköre elsődlegesen gazdaságpolitikai célok elősegítése volt. 1995-től az MBFB bekapcsolódott japán, német és európai uniós hitelek magyarországi kihelyezésébe, később regionális fejlesztési társaságokban, illetve a Rákóczi Bankban is tulajdonossá vált. Ugyanabban az évben az MBFB átvette a Pénzügyminisztériumtól a Pénzintézeti Központot, az Investbankban és a Konzumbankban is résztulajdonos lett. Az Investbank még abban az évben beolvadt a PK Bankba, a Konzumbankot 2003-ban az MKB-nak értékesítették, ezzel megszűnt az MFB csoportjában a kereskedelmi banki tevékenység. 2001-től külön törvény szabályozza a működését. 


\subsubsection{EXIM Bank (2,7\%)}

1994-ben alapították külön törvényben foglalt felhatalmazás alapján, az Exportgarancia Rt. egyes feladatainak (exportfinanszírozás és biztosítás) a továbbvitele céljából. Alapításától az MFB csoport tagja.

\subsubsection{Sberbank (1\%)}

1992-ben alapította az osztrák Volksbank-csoport. A tulajdoni szerkezete a Volksbank általi értékesítésig folyamatosan változott, azonban névadó anyabankja mindig többségi tulajdonosa volt. Tevékenységét alapítása után egy évvel kezdte meg. A bank lassú építkezéssel 2001-re érte el az 1 százalékos piaci súlyt. 2007-ben jelentős portfóliót és piaci hálózatot vett át az ÁÉB-től, ez néhány tized százalékkal megnövelte piaci részesedését, a 2 százalékot azonban nem sikerült elérnie mind a mai napig. 2012-ben a régiós hálózatot üzemeltető anyabankját értékesítette a Volksbank csoport az orosz Sberbanknak, majd a következő évben magyar bank is felvette az anyabanki csoportnevet. A bank átvételét követően a piaci súlya folyamatos csökkenésnek indult, és ma ismét az 1 százalékos küszöbértéken található.

\subsubsection{Commerzbank (o,8\%)}

1991-ben nyitotta meg képviseleti irodáját Budapesten, és 1993-ban kapott kereskedelmi banki jogosítványokat. Az évtized végéig töretlen volt a fejlődése, középbanki méretre fejlődött 2 százalékos piaci részesedést elérve. A 2000-es évek első évtizedének piacemelkedéséből azonban csak az átlagtól elmaradóan profitált, így piaci súlya fokozatosan visszaesett, és az évtized derekától 1 százalékos szint körül stabilizálódott. A 2008-as fiókteleppé alakítási időszakot sajátosan oldotta meg, mivel az egybeesett az anyabanki fúziók miatt a Dresdner Bank beolvasztásával: a Commerzbank AG létrehozta magyar fióktelepét, beolvasztotta a Dresdner Bank fióktelepének eszközeit, majd mindezt átadta a Commerzbank magyar leányvállalatának, amely azóta is részvénytársasági formában van jelen a magyar piacon.

\subsubsection{KDB Bank (o,6\%)}

A koreai Daewoo Securities és a Magyar Hitelbank 1989-ben közösen hozta létre az MHB-Daewoo Bankot az Investrade Kft. jogutódjaként, annak átalakítását követően. Az MHB-tulajdonrészét 1995-ben megvette a koreai anyaintézmény, így kizárólagos tulajdonossá vált. A Daewoo-konszern (koreai elnevezése szerint chaebol) az 1997. évi ázsiai válság során csődhelyzetbe került, állami segítséggel megmenekült a felszámolástól, azonban ennek fejében profilidegen tevékenységeit le kellett választania. Így a konszern szanálását irányító Korean Development Bank (KDB) szerezte meg a magyar leánybank tulajdonjogát 2002-ben. Ennek eredményeként a rákövetkező évben a magyar bank felvette az új tulajdonos ne- 
vét. 2013-ban a bank központi szerephez jutott a KDB európai érdekeltségei körében, ami ismételt névváltoztatásban is megjelent.

A bank a Daewoo-konszern megrogyásáig folyamatosan a piaci átlagot meghaladó mértékben tudott fejlődni, és megközelítette az 1 százalékos piaci részesedést. Ezt követően azonban folyamatosan teret vesztett, és az új tulajdonos érkezéséig fél százalék alá esett a részesedése, amit a 2013-ig terjedő időszakban csak átmenetileg, rövid ideig tudott átlépni. 2013-ban sikerült pár tized százalékkal magasabb szinten stabilizálni a piaci súlyát.

\subsubsection{Deutsche Bank (o,3\%)}

1995-ben alapította az azonos nevű anyabankja kizárólagos részesedéssel, elsősorban vállalati hitelezési céllal, ami a mai napig domináns a tevékenységében. Piaci súlyát folyamatosan növelte átlagot meghaladó bővülésével egészen a 2000es évek első pár évéig, így csaknem meghaladta az 1 százalékos részesedést. Ettől az időszaktól azonban lassú csökkenéssel a piaci súlya fél százalékig esett vissza a fiókteleppé válása időpontjáig. Ekkor a súlya megfeleződött, és a mai napig ezen a szinten, kisbanki méretben üzemel.

\subsubsection{NHB Bank (0,2\%)}

Kultúrbank néven 1990-ben alakult meg többségi külföldi részesedéssel üzemelő vegyesbankként. 1992-ben a francia IndoSuez-csoport megszerezte a bank 64 százalékos többségi részesedését, és még ebben az évben a bank felvette a tulajdonos nevét. A pénzintézetnek kisbanki szerepköréből nem sikerült elörelépnie, így a francia tulajdonos 1995-ben eladta részesedését a görög Bank of Athennak, amely ekkor már a koreai Hanwha-csoport tagja volt. A bank ezt követően nem anyabankja, hanem a koreai csoport nevét vette fel. A rákövetkező évben a Hanwha koreai tagjai szereztek benne többségi tulajdont, és a csoport görög bankjánál kisebbségi rész maradt, amit néhány év alatt ugyancsak értékesítettek az előbbi körnek. A bank teljesítménye a piaci átlaghoz mérten a tulajdonosváltást követően sem javult, sőt 2003-tól fokozatosan leépült nominálisan is alacsony (10 milliárd forintot épp csak meghaladó) szintre. 2013-ban magyar tulajdonosi csoport vásárolta meg, és átnevezte evoBankra. A rákövetkező évben ismételten tulajdonosváltás történt, az intézmény azonban magyar tulajdonban maradt. Ezután gyorsabb növekedés kezdődött, a bank csaknem megnégyszerezte piaci részesedését, de még mindig messze elmarad az 1 százalékos szinttől. A bank tevékenységét 2018 decemberében ideiglenes jelleggel korlátozta az MNB.

\subsubsection{Porsche Bank (o,2\%)}

A Volkswagen-csoport járműivel összefüggő autófinanszírozásra szakosodott bankként 1994-ben hozta létre a hasonló profilú, osztrák Porsche Bank AG. Tevékenysége ebben a keretben zajlik azóta is. Az 1990-es évek legvégén, a 200o-es 
évek első felében felfutó autópiac segítségével némileg emelkedett a piaci részesedése, de lényegesen elmaradt az 1 százaléktól, és az évtized közepétől folyamatosan csökkenve, a válság időszakában nagyjából megfeleződött.

\subsection{A piaci konszolidáció, privatizáció alatt belépők (1995-1999) $)^{37}$}

\subsubsection{Fundamenta $(1,4 \%)$}

A lakás-takarékpénztári törvény hatálybalépésekor már két, a megelőző évben létrehozott külföldi többségi tulajdonú, de több magyar bank részvételével alapított lakás-takarékpénztár várta a tevékenysége megkezdésének a lehetőségét. Hozzájuk csatlakozott röviddel később egy hasonló profilú, harmadik intézmény. A Fundamentát 1996-ban alapította a Bausparkasse Schwabisch Hall AG (86 százalék) és a Takarékbank (14 százalék). A német tulajdonos 2001-ben vásárolta ki a Takarékbankot, és lett kizárólagos tulajdonos.

Ugyancsak 1996-ba jött létre magyar bankok és biztosítók (Postabank, Creditanstalt, Volksbank, Providencia és Generali) 75 százalékos többségi részvételével, illetve 25 százalékos osztrák-német (Wüstenrot és EA-Generali) kisebbségi tulajdonnal a Lakáskassza Ltp. A Wüstenrot-csoport csak 200o-ben szerezte meg a többségi tulajdonnal az ellenőrzést a Lakáskassza felett, ezt követően vette fel a Lakáskassza-Wüstenrot nevet az intézmény.

A két lakás-takarékpénztár fej-fej mellett haladt a versenyben, piaci átlagot meghaladó bővülésük miatt részesedésüket folyamatosan növelték 2002-es összeolvadásukig. Ennek során a Fundamenta az eszközeinek bővítésében járt némileg előrébb, míg a Lakáskassza eredményesebb volt, hiszen a negyedik évét követően már nyereséget tudott termelni.

1998-ban jött létre az Otthon Lakástakarékpénztár a Dies Bausparkasse többségi tulajdonlásával. Az alapítói között volt a Konzumbank és az Erste Bank. 2002-ben beolvadt a Lakáskassza-Wüstenrot Ltp.-be. Érdemi részesedést önálló működésének néhány évében nem tudott elérni, és folyamatosan veszteségesen működött.

2002-ben a két külföldi tulajdonú lakás-takarékpénztár fuzionált a korábbi saját tőkének megfelelő arányok szerinti tulajdoni részesedésekkel, és mindkettőjük nevét felvéve. A fúziót követően töretlen volt az új intézmény fejlődése, mára csaknem másfél százalékos a piaci súlya. A lakás-takarékpénztári megtakarításokkal összefüggésben adott állami támogatás 2018 októberi megszüntetése azonban

37 Alapításuk időpontja szerint a következő bankok is ebbe a csoportba tartoznak, azonban beolvadásuk, átalakulásuk, illetve megszűnésük okán más címen belül tárgyalom azokat: LakáskasszaWüstenrot, GMAC Bank, Rabobank, Société Générale Bank, Credigen Bank (későbbi Quaestor Bank), OTP Lakástakarék, FHB Jelzálogbank (mai Takarék Jelzálogbank), Otthon Lakástakarék, HypoVereinz Jelzálogbank (mai UniCredit Jelzálogbank). 
vélhetően üzleti modelljének felülvizsgálatára készteti az intézményt a további hasonló siker fenntartása érdekében.

\subsubsection{Cetelem Bank (o,3\%)}

1996-ban alapította az áruhitelezésre szakosodott francia Le Cetelem csoport (50 százalék), illetve az MFB és az akkori leánybankja, a Konzumbank (25-25 százalék) a külföldi tulajdonos profiljával megegyező magyar tevékenység céljából. 1999ben az anyabankja, a BNP Paribas-csoport tagjává vált, majd ezzel is összefüggésben, egy évvel később kivásárolta a magyar részvényeseket. Ezzel új lendületet kapott a tevékenysége: öt év alatt megnégyszerezte a piaci részesedését (ám az így sem érte el a fél százalékot), és a korábbi veszteségeket követően, ettől a ponttól folyamatosan pozitív eredményt produkált. 2003-ban szerezte meg a pénzügyi szolgáltatások teljes körére kiterjedő jogosítványait. Azonban ez nem segítette piaci súlyának megtartásában, ettől az időszaktól kezdve folyamatosan teret vesztett. ${ }^{38}$

\subsection{A boom alatt belépők $(2000-2007)^{39}$}

\subsubsection{Bank of China $(6,2 \%)$}

A kínai pénzintézet 2003-ban hozta létre magyar leánybankját. 2013-ig a magyar piacon betöltött szerepe marginális volt, messze 1 százalék alatti piaci részesedéssel. Jelentős fordulatot hozott, hogy az anyabankja 2014-ben stratégiai együttműködést kötött a magyar kormánnyal, a kereskedelmi bankja mellett működő fióktelepet alapított Budapesten, és a magyarországi érdekeltségeiből látta, látja el a regionális tevékenysége irányítását. Ennek hatására, elsősorban a fióktelep bővülése következtében, rendkívüli sebességgel növelve piaci részesedését, mára nagybankká vált a hazai piacon.

\subsubsection{Oberbank AG Magyarországi Fióktelep (o,4\%)}

2007-ben létesített fióktelepet Magyarországon a linzi székhelyű Oberbank AG. Piacra lépése óta az átlagot meghaladó bővülést produkált a magyar területen, 2017 végéig fél százalék közeli piaci részesedést ért el.

\subsubsection{Cofidis (0,2\%)}

A francia Cofidis S.A. 2005-ben indította el fióktelepi működését Magyarországon. A piaci átlagot alig meghaladóan bővült, amin a 2006-ban alapított Banif Plusz Bank 2016 év végi beolvasztása sem lendített jelentősen.

38 Érdekesség: a Cetelem nyújtott elsőként interneten keresztül személyi hiteleket 2006-tól.

39 Alapításuk időpontja szerint a következő bankok is ebbe a csoportba tartoznak, azonban beolvadásuk, átalakulásuk, illetve megszűnésük okán más címen belül tárgyalom azokat: Dresdner Bank (majd fióktelep), OTP Jelzálogbank, AXA Bank, Allianz Bank, FHB Kereskedelmi Bank (ma Takarék Kereskedelmi Bank), Kinizsi Bank. 


\subsubsection{Sopron Bank Burgenland (0,2\%)}

Az osztrák alapítója 2003-ban hozta létre magyar leánybankját EB und Hypo Bank Burgenland-Sopron Rt. néven. Magyarországi stratégiája regionális kiterjedésű, nyugat- és észak-dunántúli és budapesti jelenléttel. Sokáig az egyetlen vidéki székhelyű bank volt. Anyabankját 2006-ban privatizálták; majd a GRAWEcsoport tagjává vált. 2016-ban a bank tulajdonjogát akkori anyabankja továbbadta egy a 100 százalékos tulajdonában lévő holdingnak. Regionális szerepköréből adódóan a bank piaci súlya is mérsékelt tempóban emelkedett az alapítása évtizedének végéig o,3 százalékig, majd ezt követően fokozatosan veszített teret.

\subsection{Késői belépők (2008-tól) ${ }^{40}$}

\subsubsection{MagNet Bank (0,4\%)}

A HBW Express Bank az 1995-ben alapított, azonos nevű takarékszövetkezet bankká alakulásával jött létre 2008-ban. Az átalakulás során a spanyol Caja Navarra Takarékbank 30 százalékos részesedést szerzett tőkeemelés útján. 2010ben a nevét megváltoztatta MagNet Bankra. 2013-ban két fontos folyamatként a bank felvásárolta és beolvasztotta a Banco Popolare magyar leánybankját, valamint kivásárolta a spanyol részvényest, így újra 100 százalékban magyar tulajdonba került. A bank folyamatosan növekedéssel és banki működése alatt pozitív eredménnyel közel fél százalékos részesedést ért el 2017 végéig.

\section{Banco Popolare Bank}

A Nemzetközi Kereskedelmi Bankot (IC Bank) 1993-ban 7 maláj magánszemély hozta létre. Sokáig a legkisebb kereskedelmi bank volt Magyarországon. 2007-ben megvásárolta a Banco Popolare-csoport, a bank ezt követően egy éven belül megduplázta a piaci részesedését, azonban a válság időszakában lelassult a fejlődése, így az olasz tulajdonosa hamarosan az értékesítéséről döntött.

\subsubsection{Duna Takarék Bank (o,2\%)}

A győri székhelyü Duna Takarékszövetkezetet 2013-ban alakították bankká Duna Takarék Bank néven, így jogelődje kimaradt az SZHISZ vezette takarékszövetkezeti integrációból. Fennállása alatt nem sikerült jelentősen elörelépnie, de sikerült szinten tartania a piaci súlyát, és jellemzően pozitív eredményességgel működött.

40 Alapításuk időpontja szerint a következő bankok is ebbe a csoportba tartoznak, azonban beolvadásuk, átalakulásuk, illetve megszűnésük okán más címen belül tárgyalom azokat: Bank Sal. Oppenheim Fióktelep, BNP Paribas és BNP Paribas Securities Fióktelepek, Commerzbank Fióktelep, Fortis Bank Fióktelep, HBW Express Bank (most MagNet Bank), SPE Bank (későbbi Széchenyi Bank), BRB Bank, DRB Bank, ÉRB Bank, Dél-Dunántúli Takarék Bank, Erste Lakástakarékpénztár, Pannon Takarék, Bank of China Fióktelep, Erste Jelzálogbank, K\&H Jelzálogbank. 


\title{
2.5.3. Aegon Lakástakarékpénztár (0,1\%)
}

Az Aegon Lakástakarékpénztár 2013-ban kezdte meg a müködését. Alapítását követően folyamatosan bővülve tudott piacot építeni, azonban állandó negatív jövedelmezőség mellett. A lakás-takarékpénztári megtakarítások állami támogatásának 2018. októberi megvonása bizonytalanná teszi a jövőjét.

\subsubsection{Mohácsi Takarék Bank (0,1\%)}

Az 958-ban alapított jogelőd takarékszövetkezet 2008-ban alakult át kereskedelmi bankká. 2014-ig lassan növelte piaci részesedését, azonban ezt követően folyamatosan teret vesztett.

\subsubsection{Polgári Bank (o,1\%)}

Az 1972-ben alapított Polgári Takarék 2013 végén alakult át kereskedelmi bankká, így hasonlóan a Duna Takarék Bankhoz, kimaradt az SZHISZ vezette takarékszövetkezeti integrációból. Érdekesség, hogy ezen a néven már történt bankalapítás. Jelenleg a legkisebb részvénytársasági formában müködő kereskedelmi bank Magyarországon.

\subsection{Röviden a Bankszövetség érdekképviseleti ernyője alá ma nem tartozó bankokról}

\begin{abstract}
Általános Értékforgalmi Bank
Az eredetileg 1922 óta működő intézmény (Magyar Ipari és Kereskedelmi Ellenőrző Bank) és az 1952 óta ezen a néven müködő bank 1987-ben kereskedelmi banki jogosítványt kapott 75 százalékos állami és 25 százalékos magyar banki részesedéssel (OTP, ÁVB). 1990-ben a banki részesedéseket és az állami részből 25 százalékot (így összesen 50 százalékot) a nemzetközi CEDC-csoport ${ }^{41}$ részére értékesítettek, így vegyesbankká vált. A bankkonszolidációban nem vett részt, azonban 1995ben jelentős tőkevesztést szenvedett el. Egy évvel később privatizálták az orosz Gazprom Banknak, amely feltőkésítette. Az új tulajdonos részvételével a piaci részesedése az ezredfordulóig két és félszeresére, csaknem 4 százalékra növekedett, majd ezt követően folyamatosan teret vesztett, és állományának, valamint hálózatának a Volksbankhoz kerüléséig (2007) 1 százalék körüli szintre esett a súlya. Ezen az sem segített, hogy anyabankja 2004-2006 között a bankbeli részesedését folyamatosan értékesítette a vezérigazgatója érdekeltségében lévő cég részére. A Volksbank-ügyletet követően 2007-ben befektetési vállalkozássá alakult át.
\end{abstract}

41 CEDC - Central European Development Corporation. 


\begin{abstract}
AXA Bank
Az elsősorban internetes szolgáltatásokat kínáló EuroDirekt Országos Takarékszövetkezetben 2003-ban többségi részesedést szerzett a Mortgage Holding S.A., majd 2004-ben átalakította azt fókuszáltan jelzáloghiteleket folyósító kereskedelmi bankká ELLA Bank néven. 2007-ben vette meg a belga AXA Csoport, majd 2008-ban módosították a nevét AXA Bankra. A rákövetkező évben beolvadt az anyabankba, és fióktelepként üzemelt. A tulajdonosváltást követően gyors fejlődésnek indult és három éven belül megháromszorozta a piaci súlyát, csaknem 2 százalékos részesedést elérve.

A profilja miatt a válság miatti kormányzati intézkedések különösen súlyosan érintették az intézményt, így visszaszorult a piacon, majd 2016-ban átadta az állományát az OTP Csoportnak, és kivonult Magyarországról.
\end{abstract}

\title{
Banco Primus
}

A portugál-francia hátterű Banco Primus 2007-hozta létre fióktelepét, amely 2008-tól folytat pénzügyi szolgáltatásokat, elsősorban autóhiteleket nyújt Magyarországon. 2011 év végétől az alapító bank nehézségei miatt új hitel nyújtására nem került sor, a fióktelep kizárólag a meglévő állománya gondozását végzi.

\section{BNP Paribas magyar fióktelepe}

A BKD Bank 1990-ben alakult a francia BNP, a német Dresdner és a K\&H közös vegyesbankjaként. A konszolidáció miatti kényszer hatására a K\&H már 1995-ben értékesítette a tulajdonrészét a másik két banknak, amelyek így paritásos részesedést szereztek, és a bankot átnevezték BNP-Dresdner Bankká. Működésének első tíz évében a bank 1 százalékot alig meghaladó részesedést tudott elérni. 2001-ben kivált a Dresdner Bank is, így a BNP Paribas 100 százalékos tulajdonossá vált, azonban a tiszta profil sem hozott érdemi változást a piaci súlya tekintetében. 2006-ban a BNP létrehozta magyar fióktelepét, amely átvette a magyar bank eszközeinek nagy részét, azonban a tulajdonos azt csak 2008-ban vezette ki a bankpiacról. Ekkorra lezárult a magyarországi struktúra kialakítása (ideértve a BNP Paribas Securities magyar fióktelepét), de ez sem hozott érdemi előrelépést a piaci részesedés növelésében.

\section{Crédit Agricole Bank magyar fióktelepe}

A Crédit Lyonnais bankot 1992-ben hozta létre azonos nevű anyabankja. Ebben az időszakban marginális szereplő volt fél százalék alatti piaci részesedéssel. 2003ban a Crédit Agricole felvásárolta a tőkéjét vesztett Credit Lyonnais-t, így 2004ben a magyar leánybank is a Calyon nevet vette fel. Az átvétel során némi lendületet kapott, és elérte az 1 százalékos piaci súlyt, de 2007-től ismét visszaesett a fél százalék körüli szintre. 2008-ban fiókteleppé alakult, azonban ez sem hozott 
előrelépést a versenyben. 2010-ben a tulajdonos névváltását követően vette fel a Crédit Agricole nevet. 2012-ben kivonult a magyar piacról.

\section{Quaestor Bank}

A Credigen Bankot fogyasztási hitelekre specializált bankként 1999-ben alapította a francia Sofinco S.A (amelynek tulajdonosa a Crédit Agricole-csoport volt) és az Euroleasing, előbbi 85 százalékos részesedésével. 2000-től már kizárólagos tulajdonossá vált a Sofinco, és ettől az évtől üzemelt ténylegesen. Piaci súlya marginális volt teljes üzemelése alatt. A Quaestor-csoport 2015-ös összeomlása előtt vásárolta meg, így onnantól valódi banki tevékenységet már nem folytatott. 2018 végén szűnt meg végelszámolással.

\section{DRB Bankcsoport}

BRB BUDA Regionális Bank Zrt.

Dél-Dunántúli Takarék Bank Zrt.

DRB Dél-Dunántúli Regionális Bank Zrt.

ÉRB Észak-magyarországi Regionális Bank Zrt.

A DRB Bank 2009-ben alakult át a siklósi székhelyü takarékszövetkezetből. Mérete 2013-ig, a bankcsoport létrejöttéig nominálisan is stagnált. A csoport többi tagja ugyancsak takarékszövetkezetek átalakulásával létrejövő kisbank, ezek az SZHISZ vezette takarékszövetkezeti integrációt elkerülendő alakultak át 2013ban. A csoport és a Buda-Cash Brókerház között szoros összefonódás alakult ki, aminek az eredményeként a brókerház összeomlása 2015-ben magával rántotta a csoport intézményeit is, felszámolásuk jelenleg is tart.

\section{Dunabank}

1987-ben hozta létre az MHB leánybankként, majd 1989-ben alakult át részvénytársasággá, és szerzett banki jogosítványokat. Ennek során a részesedések egyharmada az államhoz, kétharmada magánbefektetőkhöz került. A transzformációs válságban jelentős veszteségeket szenvedett el, így részt vett hitel és bankkonszolidációban. Tevékenységét azonban nem tudta teljes körüen reorganizálni, így 1997-ben felszámolás alá került.

\section{Európai Kereskedelmi Bank}

Két magyar (OTP, MKB) és két külföldi bank (Bank Austria és egy lombard takarék) egyenlő részesedésével 1990-ben alapított vegyesbank, amely a Bank Austria első magyar banki érdekeltsége. A tulajdonosok egy évvel később kivásárolták az MKB részesedését, majd 1993-ban az OTP tulajdonrészét is. 1997-ig átlagon felül bővült, azonban így is csak 1 százalékos piaci részesedést sikerült elérnie. 1998ban a Bank Austria-Creditanstalt-fúzió következtében a Bank Austria újabb, 
jobban teljesítő magyar érdekeltséghez jutott, így a két tulajdonos a bankot értékesítette a magyar Citibanknak, amely beolvasztotta.

\section{GMAC Bank}

A GMAC Detroit alapította 1996-ban Opel Bank néven, kifejezetten a GM-csoportba tartozó márkák kereskedelmének finanszírozása céljával. 2002-ben rövid időre felvette az anyaintézmény nevét, majd beszüntette banki tevékenységét, és pénzügyi vállalkozásként müködött tovább.

\section{ING Bank magyar fióktelepe}

1991-ben hozta létre holland anyabankja kizárólagos tulajdonlással. 1997-ig átlag feletti állománybővüléssel 2 százalékos piaci részesedést ért el. Ehhez hozzájárult, hogy 1996-ban átvette a Dunabank eszközeit és teljes operációját, ezzel a korábbi, kizárólagosan vállalati tevékenységét lakossági irányban bővítette. 2006-ig ezt a súlyt képviselte a magyar piacon, ebben rövid ideig tartó kilengést csak a bankkártyaüzletágának értékesítése okozott 200o-ben. Az ezt követő időszakban 1-2 százalék között ingadozott a piaci részesedése, és ebben nem hozott változást, hogy 2008-ban fiókteleppé alakult.

\section{Ingatlanbank}

1989-ben hozták létre a bankot ingatlanprojekt finanszírozás céljából, kereskedelmi bankok több mint 70 százalékos részesedésével. 1991-ben csendesen ki kellett vezetni a piacról.

\section{Iparbankház}

1984-től működött Ipari Szövetkezeti Fejlesztési Bank néven. 1987-ben részvénytársasággá alakult, de teljes körű banki jogosítványait csak 1990-ben szerezte meg, ezt követően vette fel az Iparbankház nevet. 1993-ban részt vett a bankkonszolidációban, müködését azonban nem tudták megfelelően reorganizálni, így 1996-an lezárta a tevékenységét és visszaadta a banki licenszét.

\section{Kinizsi Bank}

A bank 2007-ben alakult át az 1958-ban létrehozott, nagyvázsonyi székhelyű takarékszövetkezetből. Piaci súlyát banki müködésének ideje alatt nem tudta növelni, így 2019-től visszaadta banki jogosítványait, és befektetési társasággá alakult át.

\section{Leumi Hitel Bank}

1990-ben alapította az izraeli Leumi Bank és az MHB egyenlő részesedéssel. Az egyetlen vegyes tulajdonú bank volt, amely a transzformációs válság eredményeként jelentős tőkevesztést szenvedett el. Az izraeli Leumi 1995-ben értékesítette részesedését az MHB-nak, amely Silver Bank néven megkísérelte reorganizálni és értékesíteni, de végül visszaadta a banki jogosítványait. 


\section{Nomura Magyar Befektetési Bank}

1991-ben alapították többségi japán részesedéssel. Banki tevékenysége nem volt sikeres, végül 1999-ben befektetési társasággá történt átalakulással vonult ki a banki piacról.

\section{Rabobank}

A holland Rabobank 1997-ben hozta létre magyar leánybankját. Szerepe marginális maradt, fél százalékos piaci súlyt sem sikerült elérnie, emellett folyamatosan veszteséggel működött, ezért anyabankja 2002-ben pénzügyi vállalkozássá alakítva, kivonult a banki piacról.

\section{Rákóczi Bank}

1992-ben alapították állami szereplők az MFB vezetésével első vidéki székhelyű bankként. 1994-től önkormányzatok is helyet kaptak a tulajdonosi körben. Szerepe marginális maradt, ezért a tulajdonosok regionális fejlesztési társasággá alakították át 200o-ben.

\section{Reálbank}

1989-ben alapította a Budapest Bank egy igazgatósága leválasztásával. 1993-ban a $\mathrm{BB}$ eladta a részesedéseit kisbefektetőknek. Ezt követően a bank portfóliója leromlott, és a tőkéjét elveszítette. 1998-ban átvette az Országos Betétbiztosítási Alap, majd 1999-ben felszámolták.

\section{Société Générale Bank}

Miután az azonos nevű francia bank értékesítette a CIB Bank alapítása óta fennálló részesedését 1998-ban, úgy döntött, hogy kizárólagos részesedéssel alapított leánybankkal vesz rész a továbbiakban a magyar piacon. Szerepe azonban marginális maradt, így a folyamatos veszteségtermelés után 2002-ben végelszámolással megszüntette a magyar érdekeltségét.

\section{Széchenyi Kereskedelmi Bank}

2008-ben SPE Bank néven alapította magyar befektetőknek egy Kajmán-szigeteken bejegyzett társasága, és egy évvel később szerezte meg a banki jogosítványait. 2010-ben egy magyar bejegyzésü társaság szerezte meg a tulajdonát. Rövid időn belül kétszer is átnevezték, előbb Helikon Bankra, majd Széchenyi Bankra. 2013ban az állam 49 százalékos részesedést vásárolt benne, egy időben a Gránit banki befektetésével. Működése azonban egy évvel később - a tevékenység felfutását megszakítva - ellehetetlenült, és 2014-ben az MNB visszavonta a banki jogosítványait, valamint elrendelte a felszámolását. 


\section{ZÁRSZÓ}

A bankszektor 30 éves fejlődésének tanulságait nem könnyű az egyedi banki fejlődéstörténetek áttekintése alapján levonni. A bankszektor általános vonulatai mögött nagyon változatos események zajlottak.

A szektor túl van két konszolidációs időszakon, az elsőt még csak állami mankóval volt képes kezelni, az utóbbi során már elsősorban saját erőforrásai segítségével állt helyre, sőt az ország konszolidációjának forrásigényéhez is jelentős mértékben hozzájárult szektorspecifikus terheivel.

Az egész időszakban állandó volt a ki- és belépés, ezek azonban kiegyenlítetten folytak, így az időszak döntő részében a szektor mai intézményszáma körüli volt a létszám. Ezt csak tényszerủ megállapításnak szánom, és nem kívánom értékelni, hogy ez sok-e vagy kevés (azaz a szakirodalomban foglaltak szerint vajon azért magasak-e a banki árak, mert nem mérethatékony a szektor, vagy azért, mert oligopolisztikusan működik - bár vannak, akik vitatják, hogy valóban magasak-e az árak). A verseny erős jelenlétét mindenesetre az is alátámasztani látszik, hogy mennyire változékonyak a banki rangsorok.

$\mathrm{Az}$ is bizonyos, hogy mára az Európai Unió bankrendszerébe szervesen integrált bankok a magyar bankszektor éllovasai, és ez előrevetíti, hogy a következő nevezetes évfordulón is egy összességében jól működő, versenyző bankszektorról adhatunk ismét számot. 


\section{MELLÉKLET}

A LEGFONTOSABB BANKCSOPORTOK, BANKOK EGYES MUTATÓI

2. táblázat

Az OTP Bank Csoport szektorbeli tagjainak összegzett adatai

\begin{tabular}{|c|c|c|c|c|c|c|c|c|c|c|c|c|c|c|c|}
\hline & $\mathbf{1 9 8 9}$ & $\mathbf{1 9 9 0}$ & $\mathbf{1 9 9 1}$ & $\mathbf{1 9 9 2}$ & $\mathbf{1 9 9 3}$ & $\mathbf{1 9 9 4}$ & $\mathbf{1 9 9 5}$ & $\mathbf{1 9 9 6}$ & $\mathbf{1 9 9 7}$ & $\mathbf{1 9 9 8}$ & $\mathbf{1 9 9 9}$ & $\mathbf{2 0 0 0}$ & $\mathbf{2 0 0 1}$ & $\mathbf{2 0 0 2}$ & $\mathbf{2 0}$ \\
\hline $\begin{array}{c}\text { Piaci } \\
\text { része- } \\
\text { sedés }\end{array}$ & $33,5 \%$ & $34,4 \%$ & $31,7 \%$ & $33,6 \%$ & $31,6 \%$ & $30,6 \%$ & $29,4 \%$ & $28,5 \%$ & $26,3 \%$ & $25,7 \%$ & $25,0 \%$ & $23,2 \%$ & $23,6 \%$ & $25,1 \%$ & $\mathbf{2}$ \\
\hline RoA & $1,5 \%$ & $2,2 \%$ & $0,3 \%$ & $0,2 \%$ & $0,1 \%$ & $0,7 \%$ & $0,7 \%$ & $0,9 \%$ & $1,2 \%$ & $1,4 \%$ & $1,7 \%$ & $1,8 \%$ & $1,9 \%$ & $2,1 \%$ & \\
\hline RoE & $57,2 \%$ & $55,1 \%$ & $7,6 \%$ & $4,2 \%$ & $2,2 \%$ & $19,0 \%$ & $16,4 \%$ & $20,6 \%$ & $27,3 \%$ & $29,7 \%$ & $31,2 \%$ & $28,7 \%$ & $26,9 \%$ & $25,8 \%$ & \\
\hline
\end{tabular}

3. táblázat

A K\&H Bank Csoport szektorbeli tagjainak összegzett adatai

\begin{tabular}{|c|c|c|c|c|c|c|c|c|c|c|c|c|c|c|}
\hline & 1989 & 1990 & 1991 & 1992 & 1993 & 1994 & 1995 & 1996 & 1997 & 1998 & 1999 & 2000 & 2001 & 2002 \\
\hline $\begin{array}{l}\text { Piaci } \\
\text { része- } \\
\text { sedés }\end{array}$ & $11,4 \%$ & $11,8 \%$ & $10,2 \%$ & $10,5 \%$ & $8,8 \%$ & $7,5 \%$ & $6,8 \%$ & $8,1 \%$ & $8,1 \%$ & $7,9 \%$ & $7,4 \%$ & $7,1 \%$ & $11,9 \%$ & $11,1 \%$ \\
\hline RoA & $2,3 \%$ & $3,0 \%$ & $1,4 \%$ & $-0,4 \%$ & $-19,3 \%$ & $0,4 \%$ & $0,8 \%$ & $0,9 \%$ & $0,3 \%$ & $-0,6 \%$ & $-1,8 \%$ & $-0,3 \%$ & $-0,5 \%$ & $0,5 \%$ \\
\hline RoE & $23,5 \%$ & $32,2 \%$ & $16,1 \%$ & $-5,0 \%$ & $-333,3 \%$ & $10,8 \%$ & $16,0 \%$ & $17,0 \%$ & $4,1 \%$ & $-8,2 \%$ & $-34,7 \%$ & $-6,4 \%$ & $-8,1 \%$ & $8,8 \%$ \\
\hline
\end{tabular}




\begin{tabular}{|l|l|l|l|l|l|l|l|l|l|l|l|l|l|l|}
\hline $\mathbf{2 0 0 3}$ & $\mathbf{2 0 0 4}$ & $\mathbf{2 0 0 5}$ & $\mathbf{2 0 0 6}$ & $\mathbf{2 0 0 7}$ & $\mathbf{2 0 0 8}$ & $\mathbf{2 0 0 9}$ & $\mathbf{2 0 1 0}$ & $\mathbf{2 0 1 1}$ & $\mathbf{2 0 1 2}$ & $\mathbf{2 0 1 3}$ & $\mathbf{2 0 1 4}$ & $\mathbf{2 0 1 5}$ & $\mathbf{2 0 1 6}$ & $\mathbf{2 0 1 7}$ \\
\hline $26,2 \%$ & $25,8 \%$ & $25,8 \%$ & $26,7 \%$ & $27,1 \%$ & $25,0 \%$ & $27,7 \%$ & $26,1 \%$ & $26,8 \%$ & $28,1 \%$ & $28,4 \%$ & $29,2 \%$ & $27,1 \%$ & $26,5 \%$ & $27,2 \%$ \\
\hline $2,6 \%$ & $3,7 \%$ & $3,3 \%$ & $3,7 \%$ & $2,1 \%$ & $1,0 \%$ & $1,6 \%$ & $1,4 \%$ & $1,7 \%$ & $0,8 \%$ & $1,6 \%$ & $-1,4 \%$ & $0,0 \%$ & $2,6 \%$ & $3,1 \%$ \\
\hline $31,0 \%$ & $41,7 \%$ & $35,4 \%$ & $36,3 \%$ & $19,9 \%$ & $9,9 \%$ & $15,9 \%$ & $12,1 \%$ & $14,0 \%$ & $5,8 \%$ & $11,3 \%$ & $-11,1 \%$ & $0,3 \%$ & $20,5 \%$ & $20,6 \%$ \\
\hline
\end{tabular}

\begin{tabular}{|l|l|l|l|l|l|l|l|l|l|l|l|l|l|l|}
\hline $\mathbf{2 0 0 3}$ & $\mathbf{2 0 0 4}$ & $\mathbf{2 0 0 5}$ & $\mathbf{2 0 0 6}$ & $\mathbf{2 0 0 7}$ & $\mathbf{2 0 0 8}$ & $\mathbf{2 0 0 9}$ & $\mathbf{2 0 1 0}$ & $\mathbf{2 0 1 1}$ & $\mathbf{2 0 1 2}$ & $\mathbf{2 0 1 3}$ & $\mathbf{2 0 1 4}$ & $\mathbf{2 0 1 5}$ & $\mathbf{2 0 1 6}$ & $\mathbf{2 0 1 7}$ \\
\hline $\mathbf{1 0} \%$ & $10,2 \%$ & $10,2 \%$ & $9,6 \%$ & $9,3 \%$ & $10,0 \%$ & $9,4 \%$ & $10,0 \%$ & $8,8 \%$ & $8,3 \%$ & $8,7 \%$ & $7,9 \%$ & $8,2 \%$ & $8,7 \%$ & $8,7 \%$ \\
\hline $0,2 \%$ & $1,6 \%$ & $1,0 \%$ & $0,6 \%$ & $1,5 \%$ & $0,5 \%$ & $0,6 \%$ & $0,9 \%$ & $0,1 \%$ & $1,0 \%$ & $0,8 \%$ & $-0,6 \%$ & $1,3 \%$ & $1,7 \%$ & $1,4 \%$ \\
\hline $3,2 \%$ & $21,8 \%$ & $13,4 \%$ & $8,5 \%$ & $21,4 \%$ & $8,3 \%$ & $10,5 \%$ & $19,4 \%$ & $3,0 \%$ & $14,6 \%$ & $10,1 \%$ & $-8,0 \%$ & $16,4 \%$ & $19,9 \%$ & $15,7 \%$ \\
\hline
\end{tabular}




\section{4. táblázat}

\section{Az Erste Bank Csoport szektorbeli tagjainak összegzett adatai}

\begin{tabular}{|c|c|c|c|c|c|c|c|c|c|c|c|c|c|c|}
\hline & 1989 & 1990 & 1991 & 1992 & 1993 & 1994 & 1995 & 1996 & 1997 & 1998 & 1999 & 2000 & 2001 & 2002 \\
\hline $\begin{array}{l}\text { Piaci } \\
\text { része- } \\
\text { sedés }\end{array}$ & $0,7 \%$ & $0,9 \%$ & $1,3 \%$ & $1,3 \%$ & $1,3 \%$ & $1,1 \%$ & $1,1 \%$ & $2,2 \%$ & $2,0 \%$ & $2,1 \%$ & $2,2 \%$ & $2,3 \%$ & $2,9 \%$ & $3,6 \%$ \\
\hline RoA & $3,6 \%$ & $4,4 \%$ & $1,3 \%$ & $-3,3 \%$ & $-24,5 \%$ & $-0,1 \%$ & $-1,5 \%$ & $0,9 \%$ & $0,1 \%$ & $-3,1 \%$ & $0,0 \%$ & $0,2 \%$ & $0,0 \%$ & $0,3 \%$ \\
\hline RoE & $13,7 \%$ & $21,4 \%$ & $11,7 \%$ & $-47,5 \%$ & $-1085,2 \%$ & $-386,7 \%$ & $-1147,9 \%$ & $30,5 \%$ & $3,3 \%$ & $-67,6 \%$ & $1,0 \%$ & $4,1 \%$ & $1,0 \%$ & $6,1 \%$ \\
\hline
\end{tabular}

\section{5. táblázat}

\section{A Raiffeisen Bank adatai}

\begin{tabular}{|c|c|c|c|c|c|c|c|c|c|c|c|c|c|c|c|}
\hline & $\mathbf{1 9 8 9}$ & $\mathbf{1 9 9 0}$ & $\mathbf{1 9 9 1}$ & $\mathbf{1 9 9 2}$ & $\mathbf{1 9 9 3}$ & $\mathbf{1 9 9 4}$ & $\mathbf{1 9 9 5}$ & $\mathbf{1 9 9 6}$ & $\mathbf{1 9 9 7}$ & $\mathbf{1 9 9 8}$ & $\mathbf{1 9 9 9}$ & $\mathbf{2 0 0 0}$ & $\mathbf{2 0 0 1}$ & $\mathbf{2 0 0 2}$ & $\mathbf{2 0 0}$ \\
\hline $\begin{array}{c}\text { Piaci } \\
\text { része- } \\
\text { sedés }\end{array}$ & $0,9 \%$ & $1,3 \%$ & $1,3 \%$ & $1,3 \%$ & $1,4 \%$ & $1,6 \%$ & $2,1 \%$ & $2,5 \%$ & $3,0 \%$ & $3,0 \%$ & $3,5 \%$ & $4,0 \%$ & $4,9 \%$ & $5,0 \%$ & \\
\hline RoA & $3,9 \%$ & $3,9 \%$ & $4,2 \%$ & $4,2 \%$ & $4,7 \%$ & $5,9 \%$ & $7,6 \%$ & $6,3 \%$ & $3,9 \%$ & $2,9 \%$ & $1,9 \%$ & $1,7 \%$ & $2,0 \%$ & $1,7 \%$ & \\
\hline RoE & $26,0 \%$ & $39,1 \%$ & $54,4 \%$ & $40,0 \%$ & $35,7 \%$ & $43,9 \%$ & $59,4 \%$ & $50,6 \%$ & $33,2 \%$ & $24,6 \%$ & $17,4 \%$ & $17,7 \%$ & $21,8 \%$ & $18,8 \%$ & \\
\hline
\end{tabular}

\section{6. táblázat}

\section{Az MKB Bank adatai}

\begin{tabular}{|c|c|c|c|c|c|c|c|c|c|c|c|c|c|c|}
\hline & 1989 & 1990 & 1991 & 1992 & 1993 & 1994 & 1995 & 1996 & 1997 & 1998 & 1999 & 2000 & 2001 & 2002 \\
\hline $\begin{array}{l}\text { Piaci } \\
\text { része- } \\
\text { sedés }\end{array}$ & $15,0 \%$ & $14,2 \%$ & $11,1 \%$ & $9,5 \%$ & $9,1 \%$ & $8,9 \%$ & $8,9 \%$ & $7,8 \%$ & $8,2 \%$ & $9,2 \%$ & $9,2 \%$ & $9,1 \%$ & $9,5 \%$ & $8,9 \%$ \\
\hline RoA & $1,9 \%$ & $2,4 \%$ & $0,8 \%$ & $0,5 \%$ & $0,1 \%$ & $0,2 \%$ & $1,6 \%$ & $2,2 \%$ & $2,2 \%$ & $1,5 \%$ & $0,9 \%$ & $1,1 \%$ & $1,5 \%$ & $1,1 \%$ \\
\hline RoE & $46,0 \%$ & $58,1 \%$ & $18,6 \%$ & $11,0 \%$ & $1,5 \%$ & $2,7 \%$ & $22,3 \%$ & $27,8 \%$ & $22,3 \%$ & $15,0 \%$ & $10,8 \%$ & $13,1 \%$ & $18,2 \%$ & $13,0 \%$ \\
\hline
\end{tabular}




\begin{tabular}{|l|l|l|l|l|l|l|l|l|l|l|l|l|l|l|}
\hline $\mathbf{2 0 0 3}$ & $\mathbf{2 0 0 4}$ & $\mathbf{2 0 0 5}$ & $\mathbf{2 0 0 6}$ & $\mathbf{2 0 0 7}$ & $\mathbf{2 0 0 8}$ & $\mathbf{2 0 0 9}$ & $\mathbf{2 0 1 0}$ & $\mathbf{2 0 1 1}$ & $\mathbf{2 0 1 2}$ & $\mathbf{2 0 1 3}$ & $\mathbf{2 0 1 4}$ & $\mathbf{2 0 1 5}$ & $\mathbf{2 0 1 6}$ & $\mathbf{2 0 1 7}$ \\
\hline $3,8 \%$ & $7,1 \%$ & $7,8 \%$ & $8,0 \%$ & $7,8 \%$ & $8,2 \%$ & $8,6 \%$ & $9,2 \%$ & $9,7 \%$ & $9,3 \%$ & $7,8 \%$ & $6,3 \%$ & $6,1 \%$ & $6,5 \%$ & $6,7 \%$ \\
\hline $0,4 \%$ & $0,8 \%$ & $1,5 \%$ & $1,3 \%$ & $1,2 \%$ & $1,1 \%$ & $0,7 \%$ & $0,1 \%$ & $-4,8 \%$ & $-0,4 \%$ & $-0,7 \%$ & $-4,3 \%$ & $-1,1 \%$ & $1,6 \%$ & $3,5 \%$ \\
\hline $9,1 \%$ & $16,0 \%$ & $28,2 \%$ & $23,1 \%$ & $22,0 \%$ & $21,8 \%$ & $14,4 \%$ & $2,8 \%$ & $-94,3 \%$ & $-6,9 \%$ & $-9,8 \%$ & $-50,3 \%$ & $-12,1 \%$ & $14,7 \%$ & $24,0 \%$ \\
\hline
\end{tabular}

\begin{tabular}{|l|l|l|l|l|l|l|l|l|l|l|l|l|l|l|}
\hline $\mathbf{2 0 0 3}$ & $\mathbf{2 0 0 4}$ & $\mathbf{2 0 0 5}$ & $\mathbf{2 0 0 6}$ & $\mathbf{2 0 0 7}$ & $\mathbf{2 0 0 8}$ & $\mathbf{2 0 0 9}$ & $\mathbf{2 0 1 0}$ & $\mathbf{2 0 1 1}$ & $\mathbf{2 0 1 2}$ & $\mathbf{2 0 1 3}$ & $\mathbf{2 0 1 4}$ & $\mathbf{2 0 1 5}$ & $\mathbf{2 0 1 6}$ & $\mathbf{2 0 1 7}$ \\
\hline $6,1 \%$ & $6,9 \%$ & $6,9 \%$ & $7,3 \%$ & $8,1 \%$ & $8,4 \%$ & $7,6 \%$ & $7,5 \%$ & $7,1 \%$ & $7,1 \%$ & $6,3 \%$ & $6,9 \%$ & $6,3 \%$ & $6,1 \%$ & $6,2 \%$ \\
\hline $1,6 \%$ & $1,5 \%$ & $1,3 \%$ & $1,5 \%$ & $1,3 \%$ & $0,9 \%$ & $0,2 \%$ & $-0,4 \%$ & $-3,2 \%$ & $-2,7 \%$ & $-1,6 \%$ & $-5,8 \%$ & $0,4 \%$ & $0,9 \%$ & $1,4 \%$ \\
\hline $20,6 \%$ & $23,4 \%$ & $21,5 \%$ & $25,3 \%$ & $22,3 \%$ & $17,5 \%$ & $3,2 \%$ & $-7,8 \%$ & $-72,8 \%$ & $-69,3 \%$ & $-30,5 \%$ & $-188,5 \%$ & $9,8 \%$ & $11,5 \%$ & $15,4 \%$ \\
\hline
\end{tabular}

\begin{tabular}{|l|l|l|l|l|l|l|l|l|l|l|l|l|l|l|}
\hline $\mathbf{2 0 0 3}$ & $\mathbf{2 0 0 4}$ & $\mathbf{2 0 0 5}$ & $\mathbf{2 0 0 6}$ & $\mathbf{2 0 0 7}$ & $\mathbf{2 0 0 8}$ & $\mathbf{2 0 0 9}$ & $\mathbf{2 0 1 0}$ & $\mathbf{2 0 1 1}$ & $\mathbf{2 0 1 2}$ & $\mathbf{2 0 1 3}$ & $\mathbf{2 0 1 4}$ & $\mathbf{2 0 1 5}$ & $\mathbf{2 0 1 6}$ & $\mathbf{2 0 1 7}$ \\
\hline $8,4 \%$ & $9,3 \%$ & $8,9 \%$ & $8,4 \%$ & $8,9 \%$ & $8,5 \%$ & $8,9 \%$ & $8,6 \%$ & $8,2 \%$ & $7,8 \%$ & $6,4 \%$ & $6,2 \%$ & $6,2 \%$ & $6,4 \%$ & $5,9 \%$ \\
\hline $1,2 \%$ & $1,3 \%$ & $1,1 \%$ & $0,6 \%$ & $1,1 \%$ & $0,0 \%$ & $0,0 \%$ & $-4,0 \%$ & $-4,1 \%$ & $-3,5 \%$ & $-0,3 \%$ & $-2,3 \%$ & $-3,3 \%$ & $0,5 \%$ & $1,5 \%$ \\
\hline $15,2 \%$ & $17,9 \%$ & $16,3 \%$ & $9,0 \%$ & $12,9 \%$ & $0,3 \%$ & $0,1 \%$ & $-60,2 \%$ & $-101,9 \%$ & $-89,8 \%$ & $-4,6 \%$ & $-25,7 \%$ & $-42,4 \%$ & $7,9 \%$ & $20,8 \%$ \\
\hline
\end{tabular}




\section{7. táblázat}

\section{A CIB Bank adatai}

\begin{tabular}{|c|c|c|c|c|c|c|c|c|c|c|c|c|c|c|}
\hline & 1989 & 1990 & 1991 & 1992 & 1993 & 1994 & 1995 & 1996 & 1997 & 1998 & 1999 & 2000 & 2001 & 2002 \\
\hline $\begin{array}{l}\text { Piaci } \\
\text { része- } \\
\text { sedés }\end{array}$ & $3,5 \%$ & $3,7 \%$ & $3,9 \%$ & $4,0 \%$ & $4,6 \%$ & $6,0 \%$ & $7,3 \%$ & $6,9 \%$ & $6,1 \%$ & $5,9 \%$ & $7,6 \%$ & $7,8 \%$ & $8,1 \%$ & $7,7 \%$ \\
\hline RoA & $1,6 \%$ & $2,4 \%$ & $3,0 \%$ & $2,9 \%$ & $3,5 \%$ & $4,4 \%$ & $5,3 \%$ & $3,2 \%$ & $3,3 \%$ & $1,9 \%$ & $1,4 \%$ & $1,7 \%$ & $1,3 \%$ & $1,2 \%$ \\
\hline RoE & $23,1 \%$ & $42,2 \%$ & $64,5 \%$ & $45,0 \%$ & $40,1 \%$ & $116,9 \%$ & $74,3 \%$ & $25,1 \%$ & $27,4 \%$ & $18,4 \%$ & $15,5 \%$ & $20,4 \%$ & $15,7 \%$ & $15,9 \%$ \\
\hline
\end{tabular}

\section{8. táblázat}

\section{A Budapest Bank adatai}

\begin{tabular}{|c|c|c|c|c|c|c|c|c|c|c|c|c|c|c|}
\hline & 1989 & 1990 & 1991 & 1992 & 1993 & 1994 & 1995 & 1996 & 1997 & 1998 & 1999 & 2000 & 2001 & 2002 \\
\hline $\begin{array}{l}\text { Piaci } \\
\text { része- } \\
\text { sedés }\end{array}$ & $7,2 \%$ & $6,4 \%$ & $6,9 \%$ & $7,2 \%$ & $6,0 \%$ & $6,3 \%$ & $5,8 \%$ & $5,1 \%$ & $4,5 \%$ & $4,1 \%$ & $4,0 \%$ & $3,9 \%$ & $3,4 \%$ & $3,1 \%$ \\
\hline RoA & $2,1 \%$ & $3,2 \%$ & $-0,1 \%$ & $0,1 \%$ & $-8,4 \%$ & $0,9 \%$ & $1,4 \%$ & $2,4 \%$ & $1,3 \%$ & $1,0 \%$ & $0,4 \%$ & $0,5 \%$ & $0,8 \%$ & $1,9 \%$ \\
\hline RoE & $24,7 \%$ & $43,8 \%$ & $-0,9 \%$ & $1,0 \%$ & $-243,6 \%$ & $218,7 \%$ & $22,8 \%$ & $19,8 \%$ & $10,7 \%$ & $9,2 \%$ & $3,7 \%$ & $5,5 \%$ & $9,0 \%$ & $18,0 \%$ \\
\hline
\end{tabular}




\begin{tabular}{|l|l|l|l|l|l|l|l|l|l|l|l|l|l|l|}
\hline $\mathbf{2 0 0 3}$ & $\mathbf{2 0 0 4}$ & $\mathbf{2 0 0 5}$ & $\mathbf{2 0 0 6}$ & $\mathbf{2 0 0 7}$ & $\mathbf{2 0 0 8}$ & $\mathbf{2 0 0 9}$ & $\mathbf{2 0 1 0}$ & $\mathbf{2 0 1 1}$ & $\mathbf{2 0 1 2}$ & $\mathbf{2 0 1 3}$ & $\mathbf{2 0 1 4}$ & $\mathbf{2 0 1 5}$ & $\mathbf{2 0 1 6}$ & $\mathbf{2 0 1 7}$ \\
\hline $7,8 \%$ & $7,6 \%$ & $8,0 \%$ & $8,5 \%$ & $8,9 \%$ & $9,6 \%$ & $8,4 \%$ & $7,8 \%$ & $7,6 \%$ & $7,2 \%$ & $6,6 \%$ & $5,8 \%$ & $5,5 \%$ & $5,1 \%$ & $4,8 \%$ \\
\hline $1,1 \%$ & $1,5 \%$ & $1,1 \%$ & $1,0 \%$ & $0,9 \%$ & $1,0 \%$ & $0,2 \%$ & $-0,6 \%$ & $-2,1 \%$ & $-5,5 \%$ & $-5,2 \%$ & $-3,7 \%$ & $-1,3 \%$ & $0,4 \%$ & $1,3 \%$ \\
\hline $15,3 \%$ & $20,8 \%$ & $16,3 \%$ & $16,2 \%$ & $16,5 \%$ & $17,0 \%$ & $2,2 \%$ & $-6,8 \%$ & $-25,2 \%$ & $-67,6 \%$ & $-60,3 \%$ & $-39,7 \%$ & $-14,4 \%$ & $4,0 \%$ & $10,6 \%$ \\
\hline
\end{tabular}

\begin{tabular}{|l|l|l|l|l|l|l|l|l|l|l|l|l|l|l|}
\hline $\mathbf{2 0 0 3}$ & $\mathbf{2 0 0 4}$ & $\mathbf{2 0 0 5}$ & $\mathbf{2 0 0 6}$ & $\mathbf{2 0 0 7}$ & $\mathbf{2 0 0 8}$ & $\mathbf{2 0 0 9}$ & $\mathbf{2 0 1 0}$ & $\mathbf{2 0 1 1}$ & $\mathbf{2 0 1 2}$ & $\mathbf{2 0 1 3}$ & $\mathbf{2 0 1 4}$ & $\mathbf{2 0 1 5}$ & $\mathbf{2 0 1 6}$ & $\mathbf{2 0 1 7}$ \\
\hline $2,8 \%$ & $2,8 \%$ & $2,9 \%$ & $3,1 \%$ & $3,2 \%$ & $2,9 \%$ & $2,8 \%$ & $2,8 \%$ & $2,8 \%$ & $3,1 \%$ & $3,0 \%$ & $2,8 \%$ & $3,0 \%$ & $3,0 \%$ & $2,9 \%$ \\
\hline $1,9 \%$ & $2,5 \%$ & $1,1 \%$ & $0,6 \%$ & $2,1 \%$ & $1,4 \%$ & $1,1 \%$ & $0,9 \%$ & $0,5 \%$ & $1,0 \%$ & $1,1 \%$ & $-2,4 \%$ & $1,7 \%$ & $1,1 \%$ & $1,4 \%$ \\
\hline $16,3 \%$ & $21,2 \%$ & $9,6 \%$ & $6,5 \%$ & $22,5 \%$ & $14,5 \%$ & $10,5 \%$ & $7,6 \%$ & $3,9 \%$ & $7,8 \%$ & $7,6 \%$ & $-16,7 \%$ & $13,7 \%$ & $8,8 \%$ & $10,6 \%$ \\
\hline
\end{tabular}




\section{9. táblázat}

A BA-CA (Creditanstalt), a Hypo Bank Csoport

és az UniCredit Bank Csoport szektorbeli tagjainak összegzett adatai

BA-CA, később HVB, majd UniCredit

\begin{tabular}{|c|c|c|c|c|c|c|c|c|c|c|c|c|c|}
\hline & 1990 & 1991 & 1992 & 1993 & 1994 & 1995 & 1996 & 1997 & 1998 & 1999 & 2000 & 2001 & 2002 \\
\hline $\begin{array}{l}\text { Piaci } \\
\text { részesedés }\end{array}$ & $0,9 \%$ & $1,3 \%$ & $0,9 \%$ & $1,0 \%$ & $1,5 \%$ & $2,1 \%$ & $2,6 \%$ & $2,8 \%$ & $3,5 \%$ & $4,0 \%$ & $3,7 \%$ & $5,8 \%$ & $5,6 \%$ \\
\hline RoA & $5,0 \%$ & $0,5 \%$ & $1,4 \%$ & $1,1 \%$ & $2,5 \%$ & $2,7 \%$ & $2,5 \%$ & $1,6 \%$ & $1,8 \%$ & $1,5 \%$ & $1,8 \%$ & $1,4 \%$ & $1,3 \%$ \\
\hline RoE & $54,1 \%$ & $5,2 \%$ & $11,0 \%$ & $8,0 \%$ & $18,4 \%$ & $20,5 \%$ & $21,7 \%$ & $17,2 \%$ & $22,1 \%$ & $19,9 \%$ & $21,1 \%$ & $14,4 \%$ & $14,0 \%$ \\
\hline
\end{tabular}

Hypo Vereins Bank

\begin{tabular}{|c|c|c|c|c|c|c|c|c|c|c|c|}
\hline & $\mathbf{1 9 9 0}$ & $\mathbf{1 9 9 1}$ & $\mathbf{1 9 9 2}$ & $\mathbf{1 9 9 3}$ & $\mathbf{1 9 9 4}$ & $\mathbf{1 9 9 5}$ & $\mathbf{1 9 9 6}$ & $\mathbf{1 9 9 7}$ & $\mathbf{1 9 9 8}$ & $\mathbf{1 9 9 9}$ & $\mathbf{2 0 0 0}$ \\
\hline $\begin{array}{c}\text { Piaci } \\
\text { részesedés }\end{array}$ & & & & $0,2 \%$ & $0,4 \%$ & $0,6 \%$ & $0,9 \%$ & $1,5 \%$ & $2,0 \%$ & $2,3 \%$ & $2,1 \%$ \\
\hline RoA & & & & $-2,6 \%$ & $0,0 \%$ & $1,7 \%$ & $1,1 \%$ & $0,5 \%$ & $0,0 \%$ & $-0,7 \%$ & $1,0 \%$ \\
\hline RoE & & & & $-12,3 \%$ & $0,1 \%$ & $10,6 \%$ & $7,5 \%$ & $3,3 \%$ & $0,3 \%$ & $-6,2 \%$ & $9,4 \%$ \\
\hline
\end{tabular}




\begin{tabular}{|l|l|l|l|l|l|l|l|l|l|l|l|l|l|l|}
\hline $\mathbf{2 0 0 3}$ & $\mathbf{2 0 0 4}$ & $\mathbf{2 0 0 5}$ & $\mathbf{2 0 0 6}$ & $\mathbf{2 0 0 7}$ & $\mathbf{2 0 0 8}$ & $\mathbf{2 0 0 9}$ & $\mathbf{2 0 1 0}$ & $\mathbf{2 0 1 1}$ & $\mathbf{2 0 1 2}$ & $\mathbf{2 0 1 3}$ & $\mathbf{2 0 1 4}$ & $\mathbf{2 0 1 5}$ & $\mathbf{2 0 1 6}$ & $\mathbf{2 0 1 7}$ \\
\hline $5,9 \%$ & $6,4 \%$ & $6,0 \%$ & $6,4 \%$ & $6,4 \%$ & $6,0 \%$ & $5,8 \%$ & $5,3 \%$ & $5,7 \%$ & $6,0 \%$ & $6,4 \%$ & $7,5 \%$ & $9,4 \%$ & $9,2 \%$ & $8,7 \%$ \\
\hline $1,3 \%$ & $2,1 \%$ & $1,5 \%$ & $1,3 \%$ & $1,2 \%$ & $1,5 \%$ & $0,6 \%$ & $0,7 \%$ & $0,7 \%$ & $1,3 \%$ & $0,5 \%$ & $0,5 \%$ & $2,0 \%$ & $1,5 \%$ & $1,6 \%$ \\
\hline $14,9 \%$ & $24,4 \%$ & $17,6 \%$ & $16,7 \%$ & $17,5 \%$ & $22,4 \%$ & $9,3 \%$ & $9,1 \%$ & $8,8 \%$ & $15,4 \%$ & $4,8 \%$ & $5,3 \%$ & $25,4 \%$ & $17,4 \%$ & $16,3 \%$ \\
\hline
\end{tabular}




\section{0. táblázat}

\section{Az FHB Csoport és a Takarékbank Csoport szektorbeli tagjainak összegzett adatai}

2017-ben a Takarékbank csoporttal együtt

\begin{tabular}{|c|c|c|c|c|c|c|c|c|c|c|c|c|c|c|}
\hline & 1989 & 1990 & 1991 & 1992 & 1993 & 1994 & 1995 & 1996 & 1997 & 1998 & 1999 & 2000 & 2001 & 2002 \\
\hline $\begin{array}{l}\text { Piaci } \\
\text { része- } \\
\text { sedés }\end{array}$ & $1,4 \%$ & $1,5 \%$ & $1,7 \%$ & $2,1 \%$ & $1,4 \%$ & $1,3 \%$ & $1,1 \%$ & $1,5 \%$ & $1,7 \%$ & $1,7 \%$ & $1,6 \%$ & $1,3 \%$ & $1,4 \%$ & $1,6 \%$ \\
\hline RoA & $2,6 \%$ & $2,7 \%$ & $1,9 \%$ & $0,3 \%$ & $-25,7 \%$ & $0,2 \%$ & $0,6 \%$ & $0,9 \%$ & $0,8 \%$ & $0,3 \%$ & $0,1 \%$ & $0,4 \%$ & $0,8 \%$ & $0,5 \%$ \\
\hline RoE & $37,1 \%$ & $46,6 \%$ & $44,2 \%$ & $8,2 \%$ & $-1435,2 \%$ & $18,9 \%$ & $18,8 \%$ & $29,3 \%$ & $21,4 \%$ & $7,0 \%$ & $1,8 \%$ & $8,9 \%$ & $17,5 \%$ & $11,9 \%$ \\
\hline
\end{tabular}

FHB Csoport

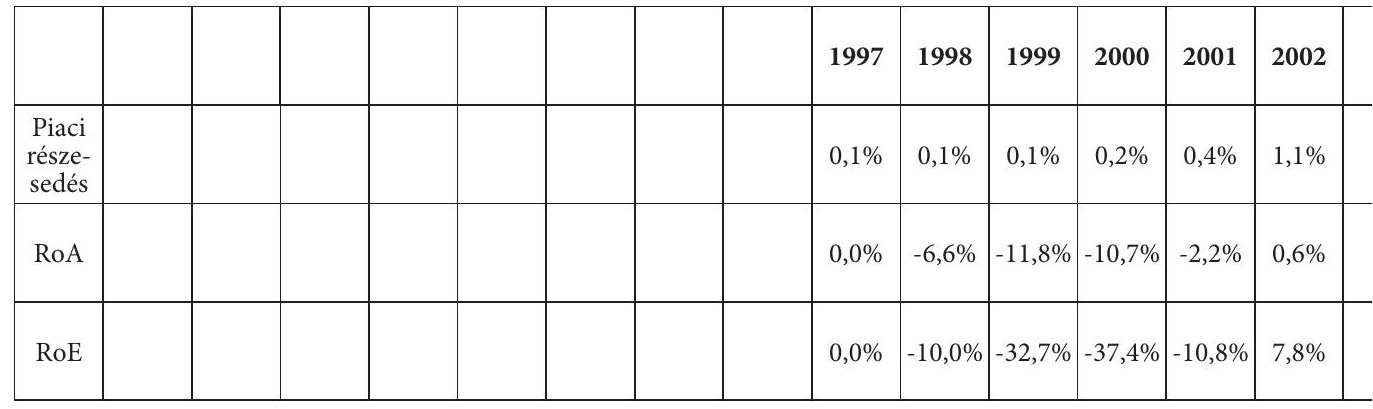




\begin{tabular}{|l|l|l|l|l|l|l|l|l|l|l|l|l|l|l|}
\hline $\mathbf{2 0 0 3}$ & $\mathbf{2 0 0 4}$ & $\mathbf{2 0 0 5}$ & $\mathbf{2 0 0 6}$ & $\mathbf{2 0 0 7}$ & $\mathbf{2 0 0 8}$ & $\mathbf{2 0 0 9}$ & $\mathbf{2 0 1 0}$ & $\mathbf{2 0 1 1}$ & $\mathbf{2 0 1 2}$ & $\mathbf{2 0 1 3}$ & $\mathbf{2 0 1 4}$ & $\mathbf{2 0 1 5}$ & $\mathbf{2 0 1 6}$ & $\mathbf{2 0 1 7}$ \\
\hline $\mathbf{1} 2 \%$ & $1,3 \%$ & $1,5 \%$ & $1,2 \%$ & $1,2 \%$ & $1,2 \%$ & $1,2 \%$ & $1,2 \%$ & $1,1 \%$ & $1,3 \%$ & $1,6 \%$ & $2,6 \%$ & $2,5 \%$ & $1,9 \%$ & $4,6 \%$ \\
\hline $0,4 \%$ & $0,5 \%$ & $0,4 \%$ & $0,4 \%$ & $0,4 \%$ & $0,2 \%$ & $0,4 \%$ & $0,2 \%$ & $0,1 \%$ & $0,1 \%$ & $0,1 \%$ & $0,3 \%$ & $0,4 \%$ & $0,4 \%$ & $0,0 \%$ \\
\hline $10,8 \%$ & $14,0 \%$ & $12,9 \%$ & $13,9 \%$ & $13,4 \%$ & $7,1 \%$ & $11,6 \%$ & $4,4 \%$ & $3,2 \%$ & $1,3 \%$ & $1,7 \%$ & $11,9 \%$ & $18,1 \%$ & $15,2 \%$ & $0,4 \%$ \\
\hline
\end{tabular}

\begin{tabular}{|l|l|l|l|l|l|l|l|l|l|l|l|l|l|l|}
\hline $\mathbf{2 0 0 3}$ & $\mathbf{2 0 0 4}$ & $\mathbf{2 0 0 5}$ & $\mathbf{2 0 0 6}$ & $\mathbf{2 0 0 7}$ & $\mathbf{2 0 0 8}$ & $\mathbf{2 0 0 9}$ & $\mathbf{2 0 1 0}$ & $\mathbf{2 0 1 1}$ & $\mathbf{2 0 1 2}$ & $\mathbf{2 0 1 3}$ & $\mathbf{2 0 1 4}$ & $\mathbf{2 0 1 5}$ & $\mathbf{2 0 1 6}$ & \\
\hline $2,3 \%$ & $2,6 \%$ & $2,6 \%$ & $2,5 \%$ & $2,7 \%$ & $2,7 \%$ & $3,2 \%$ & $3,5 \%$ & $3,6 \%$ & $3,6 \%$ & $3,8 \%$ & $3,7 \%$ & $2,8 \%$ & $2,4 \%$ & \\
\hline $1,9 \%$ & $2,3 \%$ & $1,6 \%$ & $1,3 \%$ & $0,6 \%$ & $0,6 \%$ & $0,4 \%$ & $-1,9 \%$ & $-0,8 \%$ & $-0,2 \%$ & $-0,1 \%$ & $-2,7 \%$ & $-0,6 \%$ & $-1,6 \%$ & \\
\hline
\end{tabular}




\section{HIVATKOZÁSOK}

24.hu (2007): Kis magyar banktörténelem (sz. n., https://24.hu/fn/gazdasag/2007/05/31/kis_magyar_ banktortenelem/).

Ábel István - SZAKadát LÁszló (1997): A bankrendszer átalakulása Magyarországon 1987-1996 között. Közgazdasági Szemle, XLIV. évf. 7-8. sz. 635-652. o.

ÁSZ (1996): 322. sz. Jelentés a hitel-, bank és adóskonszolidáció végrehajtásának ellenőrzéséről a Magyar Hitelbanknál, a Magyar Befektetési és Fejlesztési Banknál és a Konzumbanknál https:// www.asz.hu/storage/files/files/\%C3\%96sszes\%2ojelent\%C3\%A9s/1996/322_Jelent__s_a_hitel. pdf?ctid $=746$.

BANAI ÁdÁM - KirÁly JúlIA - NAgy MárTon (2010): Az aranykor vége Magyarországon. Külföldi szakmai és lokális tulajdonú bankok - válság előtt és válság után. Közgazdasági Szemle, LVII. évf. 2. sz. 105-131. o.

Bonin, John P. - SCHAFFer, MARK E. (1996): Bankok, vállalatok, rossz hitelek és csődök Magyarországon, 1991-1994. Közgazdasági Szemle, XLIII. évf. 2. sz. 93-113. o.

KIRÁLY JÚLIA (1995): Válságspirál, avagy a magyar bankok tőkevesztésének egy lehetséges értelmezése. Közgazdasági Szemle, XLII. évf. 9. sz. 819-837. o.

KirÁLY JÚLIA - NAGY MÁRTON (2008): Jelzálogpiacok válságban: kockázatalapú verseny és tanulságok. Hitelintézeti Szemle, 7. évf. 5. sz. 450-482. o.

Kovács Levente (2012): Banki különadók az Európai Unióban. Pénzügyi Szemle, 57. évf. 3. sz. 355367. o.

KovÁcs Levente (2014): A bankszektor helyzete és kihívásai 2013-ban. Magyar Pénzügyi Almanach 2013-2014.

Kovács Levente (2015): Hitelintézeti konszolidáció és adóskonszolidáció. Magyar Pénzügyi Almanach 2014-2015.

Magyar Parlament (1997): J 4956 sz. jelentés a Budapest Bank privatizációjának - beleértve a Polgári Bank visszavásárlásának körülményeit is - ellenőrzéséről, www.parlament.hu/iromany/ fulltext/04956txt.htm (2019.01.07).

Magyar Pénzügyi és Tőzsdei Almanachok 1990-2011/2012.

MNB (1999): A magyar bankszektor 1998. évi tevékenysége (https://www.mnb.hu/letoltes/bsz9802hu.pdf).

MNB (2000): A hitelintézeti rendszer 1999. évi tevékenysége (https://www.mnb.hu/letoltes/bsz9902hu.pdf).

Müller János - Kovács Tamás - Kovács Levente (2014): A Magyar Bankszövetség története. Budapest, Tarsoly Kiadó.

Szentpéteri ÁdÁm - Becsei András - Dányi Zsolt - Bógyi Attila (2017): Küzdelmes versenyben: a magyar bankszektor jövedelmezöségének elemzése. Gazdaság és Pénzügy, 4. évf. 4. sz. 260-285. o.

VÁRHEGYi ÉvA (1995): A magyar bankpiac szerkezete - koncentráció, szegmentáltság, jövedelmi polarizáció. Közgazdasági Szemle, XLII. évf. 3. sz. 218-235. o.

VÁrhegyi Éva (1998): A magyar banktulajdonosi szerkezet sajátos vonásai. Közgazdasági Szemle, XLV. évf. 10. sz. 906-922. o.

VÁrhegyi Éva (2001): Külföldi tulajdon a magyar bankrendszerben. Közgazdasági Szemle, XLVIII. évf. 7-8. sz. 581-598. o.

VÁrhegyi Éva (2002): Bankvilág Magyarországon. Budapest, Helikon Kiadó.

Felügyeleti statisztikák

MNB (https://www.mnb.hu/statisztika/statisztikai-adatok-informaciok/adatok-idosorok/xvifelugyeleti-statisztikak) 